\title{
Transition Period of the Dairy Cow Revisited: II. Homeorhetic Stimulus and Ketosis With Implication for Fertility
}

\author{
Holger Martens ${ }^{1}$ \\ ${ }^{1}$ Institute of Veterinary Physiology, Freie Universität Berlin, Berlin, Germany \\ Correspondence: Holger Martens, Institute of Veterinary Physiology, Freie Universität Berlin, Oertzenweg 19b, \\ 14163 Berlin, Germany. Tel: 049-30-831-1805. E-mail: holger.martens@fu-berlin.de
}

Received: November 28, 2019

Accepted: January 27, $2020 \quad$ Online Published: February 15, 2020

doi:10.5539/jas.v12n3p25

URL: https://doi.org/10.5539/jas.v12n3p25

The research is financed by the Margarete-Markus-Charity and the Bundesministerium für Bildung, Wissenschaft und Forschung.

\begin{abstract}
Dairy cows have been selected during the last century primarily for milk production, which has been increased by a factor 3-5 per lactation during this period without a concomitantly adequate increase of dry matter intake (DMI). This discrepancy between input and output is caused by a negative or minutely positive genetic correlation between milk yield and DMI and leads, in high-producing dairy cows in early lactation, to a severe and long-lasting negative energy balance (NEB) with distinct hormonal and metabolic alterations. Milk production during this period is regulated by homeorhesis with high priority for this trait, which is relatively uncoupled from DMI, and hence with possible restrictions of other functions. The extent and duration of the current NEB is a health risk and is probably one of the reasons for genetic correlations between milk yield and disease. The gap between input and output is closed by the mobilization of reserves characterized by a rapid increase of non-esterified fatty acids (NEFA) above the acute requirement, in turn leading to ectopic fat disposition in the liver and other organs. Therefore, fat liver and ketosis occur during early lactation within a phase of the priority of the homeorhetic (genetic) regulation of milk production at insufficient DMI. Ketosis is correlated with an impairment of fertility. The correlation between an early cause (ketosis) and a later effect (impaired fertility) cannot be explained satisfactorily, but possible epigenetic alterations look promising for future research. The revealed connection between homeorhesis, fat liver and ketosis, and the impairment of fertility provides an approach for discussions of these topics as a complex. The convergence between these issues should furthermore be extended to other production diseases. Since the genetic background of this interaction must not be neglected, the current breeding system should include further health traits with a predominant emphasis on parameters of metabolism and energy balance.
\end{abstract}

Keywords: homeorhesis, ketosis, fertility

\section{Introduction}

Milk production of dairy cows has been increased by a factor 3-5 per lactation during the last century. In Germany, production per lactation has been improved from $2600 \mathrm{~kg}$ in the $1950 \mathrm{~s}$ to almost $8000 \mathrm{~kg}$ in 2018 (mean of all breeds) (BRS, 2019). Single cows or herds produce much more milk, and milk yields (MY) of $11000-12000 \mathrm{~kg}$ (or even beyond that amount) are very often attained in countries with intensive milk production. Similarly, the trend for milk production has been genetically increased in the USA, and production from some $2000 \mathrm{~kg}$ in the 1920s has risen to $10328 \mathrm{~kg}$ in 2016 (Baumgard et al., 2017) and to $11970 \mathrm{~kg}$ in Israel (Israeli Dairy Board, 2017). This increase in production is the result of intense genetic selection primarily for milk yield, improved nutrition, proper management, and the careful prevention and treatment of diseases by veterinarians.

The postpartum delay between the rapid increase of MY and maximal dry matter intake (DMI) causes a period of negative energy balance (NEB), high metabolic rates, and changes of hormones and metabolites, which is exacerbated with increasing MY (see part 1) and the prevailing negative genetic correlation between MY and DMI (Karacaören et al., 2006; Liinamo et al., 2012; Manzanilla-Pech et al., 2014), although a positive energy balance has recently been described (Krattenmacher et al., 2019). The deficit of nutrients occurs during a time of 
homeorhetic (genetic) regulation of MY with high priority, with the rapid mobilization of reserves, possible metabolic stress at current performance, and hence, potential constraints and the impairment of health. Probable consequences were discussed as early as 1988 by Emanuelson who concluded: "The situation is further complicated by results showing that a genetic antagonism probably exists between production traits and disease resistance".

The possible genetic interaction between production and health has been analyzed by Berry et al. (2011) and Price et al. (2016) in comprehensive reviews. Heritability estimates of disease are low (<5\%) (Pryce et al., 2016), but genetic correlations between MY and diseases are evident (Berry et al., 2011). For instance, genetic correlations have been demonstrated between MY and ketosis (Simianer et al., 1991; Uribe et al., 1995), MY and mastitis (Koeck et al., 2014b; see review Martin et al., 2018), MY and lameness (Gernand et al., 2012; Koeck et al., 2014b), MY and retained fetal membranes (Heringstad et al., 2007), and MY and impairment of fertility (Pryce et al., 1997; Royal et al., 2002), together with an antagonistic (genetic) relationship between MY and days of productive life (Pritchard et al., 2013). Body weight changes during early lactation $(\approx$ NEB) exhibit genetic correlations with ketosis, metabolic and infectious diseases (Frigo et al., 2010), and fertility (Dechow et al., 2002). Furthermore, in a recent study concerning the genetic analysis of cow mortality and milk production, Tsuruta et al. (2017) concluded that "The increase in reliability with genomic information is particular high for cow mortality" and "the existence of a common region on Bos taurus autosome 14 affecting both traits (MY and mortality, the author) may indicate a major gene with a pleiotropic effect on milk and mortality".

Beilharz et al. (1993) approached possible genetic health risks at high MY from a theoretical point of view: resource allocation. The authors discussed some potential restrictions of fitness at continued selection for one trait at limited resources and concluded that "unless the environment (resources, the author) is being improved, antagonisms between traits will start to develop as soon as production traits are selected" (Beilharz \& Nitter, 1998). An analogous conclusion has been made by Berry et al. (2011): "Although there were a few exceptions, selection for increased milk production alone without cognizance of other traits is expected to increase the incidence of mastitis, lameness, cystic ovaries, ketosis and metritis".

The performance of farm animals requires the allocation of resources for maintenance, growth, production, and reproduction (Huber, 2017; see also resource allocation of Beilharz et al., 1993) and "genetic changes in nutrient partitioning towards production and away from other life functions are expected (in cows, the author)" (Friggens $\&$ Newbold, 2007). Hence, possible restrictions of fitness in dairy cows are facilitated by this major shift and the partitioning of nutrients for milk production at limited resources (NEB).

The genetic correlations between MY and diseases (see above) and the objections of Emanuelson (1988), Beilharz et al. (1993), Beilharz and Nitter (1998), Friggens and Newbold (2007), and Berry et al. (2011) do not offer a causal explanation, although the study of Tsuruta et al. (2017) indicates that closer genetic and possible underlying information will become available in future. MY during early lactation is correlating with NEB, and NEB clearly means limited resources and a statistical risk for health during a period of homeorhetic priority of milk secretion. However, NEB with its changes of hormones and metabolites offers some causal explanations of fresh cow or productions diseases.

The intention of this review is to promote the discussion of two types of production diseases in more detail: fat liver and ketosis as a consequence of the genetic correlation between increasing milk production and insufficient DMI at homeorhetic priority of milk production, and the impairment of fertility as a result of an explicit "primarily physiological antagonism" between production and reproduction at limited resources.

\section{Physiological and Genetic Background of Fat Liver and Ketosis as Well as Fertility}

\subsection{Fat Liver}

Pathogenesis of fat liver: Metabolic conditions of the pathogenesis of fat liver (and ketosis) have been outlined in detail by Danfær (1994), Herdt (2000), Vernon (2005), Ametaj (2005), Geelen and Wensing (2006), with fine biochemical points being made by White (2015). NEFA are released from the adipose tissue, increase in the blood, are taken up by the liver proportional to the concentration (Emery et al., 1992; Reynolds et al., 2003), and are partly metabolized including the release of $\beta$-hydroxybutyrate (BHB). The remaining NEFA are converted to TAG (triacylglycerol) and, if the re-synthesis to TAG exceeds the export as VLDL (very low density lipoprotein), accumulation occurs in liver cells and finally causes fat liver (Emery et al., 1992; Drackley et al., 2001; Katoh, 2002; Bobe et al., 2004; Ingvartsen, 2006) and further ectopic fat deposition (EFD) in non-adipose tissue (Roberts et al., 1981). The NEFA concentrations are probably associated with the expression of the mRNA of genes that are involved in the development of periparturient fat liver (Loor et al., 2005). Moreover, EFD causes 
cellular dysfunction (lipotoxicity) via potential oxidative stress and proinflammatory pathways (Montgomery et al., 2018), although the knowledge of this system in ruminants is limited (McFadden \& Rico, 2019).

DMI is also related to fat liver. Dairy cows with low DMI intake before (Bertics et al., 1992) and after (Hammon et al., 2009) parturition have a higher liver fat content. The prepartum diminished DMI can be used as "an early indicator of subclinical ketosis" (Goldhawk et al., 2009).

In addition to the classic scheme of the pathogenesis of fat liver, inflammation might contribute or accompany fat liver. Ohtsuka et al. (2001) have reported higher concentrations of the pro-inflammatory cytokine TNF- $\alpha$ in cows with moderate and high fat liver content. Ametaj (2005) has discussed the potential role of endotoxins and observed increased TNF- $\alpha$, serum amyloid A, and haptoglobin in cows with fat liver. Infusion of TNF- $\alpha$ into lactating dairy cows causes, within the liver, a significant increase of TAG and a decrease of transcript abundance of enzymes involved in gluconeogenesis (Bradford et al., 2009). The induction of ketosis by feed restriction causes a several fold increase of pro-inflammatory IL-6 expression in the liver, which "might contribute to development of liver lipidosis, ketosis, and insulin resistance" (Loor et al., 2007).

Human fat liver: Non-alcoholic fatty liver disease (NAFLD) in mankind is an extremely common disease in western societies, with NAFLD being considered as the primary event followed by oxidative stress, production of pro-inflammatory cytokines, and lipotoxicity (Gong et al., 2017). Studies of the pathophysiology of NAFLD have revealed remarkable parallels with the fat liver of cows. A growing body of evidence suggests that low growth hormone $(\mathrm{GH})$ is involved in the initiation and progression of NAFLD (Gong et al., 2017). This correlation has led to experiments with GH receptor (GHR) knockout mice (= uncoupling GH-IGF-1 axis), which exhibit notable changes from the wild-type: fat liver, a 4-fold increase of GH and very low IGF-1 concentrations, increased free fatty acids concentrations, and insulin resistance (IR) (Fan et al., 2009). These results have been confirmed by Liu et al. (2016). Furthermore, the restoration of liver IGF-1 expression in mice via hepatic IGF-1 transgene normalizes some of the changes mentioned above but does not significantly reduce liver fat content and is insufficient to resolve fat-induced oxidative stress and inflammation in the liver (Liu et al., 2016). Additionally, the uptake of free fatty acids into the liver cells via fatty acid translocase (also known as CD36) is upregulated in mice with impaired GH action in the liver (Barclay et al., 2011). The mRNA of CD36 is increased in high-yielding cows in early lactation (McCarthy et al., 2010) during a period of NEB and an uncoupled GH-IGF-1 axis (Lucy, 2004). This suggests that an increase of CD36 and NEFA uptake into the liver cells occurs, if the liver is refractory to GH. These data remain puzzling but should be integrated and, more importantly, experimentally established in ruminants: are CD36 expression and NEFA uptake (down)regulated by GH and (up)regulated by the uncoupling of the GH-IGF-1 axis?

TAG and impairment of liver function: TAG accumulation impairs liver ureagenesis (Strang et al. 1998), the conversion of ammonia to urea (Zhu et al., 2000), and glucose production (Murondoti et al., 2004), which could explain the significant correlation of fat liver with lower blood glucose concentration (Gröhn et al., 1983). This fits together with the effects of TNF- $\alpha$ infusion, namely TAG accumulation and a decrease of transcription of enzymes involved in gluconeogenesis (Bradford et al., 2009). Furthermore, fat liver is associated with a decrease of blood albumin concentration (Reid, 1982) and is correlated with multiple diseases such as the displacement of the abomasum, mastitis, metritis, and impaired immunoreactivity. According to the compilation of data by Bobe et al. (2004), the incidence of moderate fat liver (5-10\% TAG of wet weight) varies from $20-65 \%$ and of severe fat liver (> 10\% TAG) from 5-24\%.

\subsection{Ketosis}

Homeorhesis and ketosis: The possible risk of ketosis at low DMI during early lactation has been characterized by Baird (1977): "The cow will attempt to maintain milk production despite food deprivation and as a result will become ketotic" and "cows are only susceptible to the disorder (primary ketosis) during early lactation, when the homeorhetic stimulus to lactate is at a maximum" (Baird, 1981). These statements of Baird clearly underline the priority of milk production above possible health risks and suggest ketosis as a homeorhetic and genetic disease.

Fat liver and ketosis: Fat liver is believed to precede the increase of ketones in the blood (Grummer, 1993; Katoh, 2002), and hence, fat liver is accompanied p.p. by ketosis prone metabolic circumstances: high NEFA, increased production and concentrations of BHB, low glucose concentration at high demand, and probably inflammation. The proinflammatory cytokine IL-6, which regulates the hepatic synthesis of acute phase proteins, is positively related with NEFA and BHB at d 8 p.p. (Mansouryar et al., 2018) and is increased in ketotic cows (Loor et al., 2007; Rodriguez-Jimenez et al., 2018). Methylglyoxal (MGO), which is commonly used as a diagnostic parameter in diabetes type 2 in man, is significant higher in subclinical ketotic cows $\left(1.2 \mathrm{mmol} \cdot \mathrm{l}^{-1} \geq \mathrm{BHB} \leq 3.0\right.$ $\mathrm{mmol} \cdot \mathrm{l}^{-1}$ ) and is positively correlated with acute phase protein haptoglobin in lactating cows (Li et al., 2018a). 
The possible role of proinflammatory cytokines correlates with the association of inflammatory biomarkers (serum amyloid A, haptoglobin, lipopolysaccharide binding protein) in ketotic cows (Abuajamieh et al., 2016).

The usually tested blood parameters can be extended by analogous data in milk. BHB and the fat-to-protein ratio in milk are genetically correlated with clinical ketosis (Koeck et al., 2014a), and the data of Bach et al. (2019) suggest milk BHB and NEFA as promising indicators of diseases.

The metabolic alterations that occur during inflammation are accompanied by hormonal changes. Ketotic cows exhibit a significantly decreased insulin concentration (Hove, 1974; Sakai et al., 1993) and a more pronounced decrease of insulin early p.p. (Kerestes et al., 2009). The insulin response to glucose is significantly lower in cows with ketosis (Sakai et al., 1993; Kerestes et al., 2009) suggesting IR. Insulin stimulates the peripheral utilization of ketones (see the literature, especially Brockman, 1979; Hayirli, 2006) and decreases hepatic ketone production (Hayirli, 2006), which may be impaired at low insulin concentration. The treatment of ketotic cows with glucose (day 1-5) or glucose + insulin (day 2-4) supports this outcome. NEFA and ketone bodies were lower and glucose higher at $\mathrm{d} 6$ in a group of cows receiving glucose + insulin compared cows treated with glucose alone (Sakai et al., 1993). The low insulin concentration as a health risk in ketotic cows has been emphasized as early as 1976 by Brockman and 1986 by Giesecke.

Lower IGF-1 and higher GH concentrations have been measured in cows with clinical ketosis (Du et al., 2018), and the application of GH causes high NEFA and ketone concentrations (Kronfeld, 1965). The latter author suggests "excessive secretion of endogenous GH could conceivably play a role in the pathogenesis of naturally occurring bovine ketosis". This suggestion agrees with a recent observation. Holstein and Jersey cows were treated a.p and p.p with recombinant bovine somatotropin (rbST). This treatment did not influence blood BHB concentration but numerically increased ketosis (Silva et al., 2017a). However, a further study of periparturient treatment with rbST resulted in a decreased p.p. BHB concentration (Silva et al., 2017b).

Uncoupling of the GH-IGF-1 axis: Ketotic cows exhibit, in addition to the discussed metabolic and hormonal changes, an uncoupling of the GH-IGF-1 axis (Du et al., 2018): an increase of GH and a decrease of IGF-1. Furthermore, in calf liver cells in vitro, NEFA or BHB causes a reduction of GHR 1A and IGF-1 mRNA expression (uncoupling of GH-IGF-1 axis) (Du et al., 2018) and explains the earlier observation of a negative correlation between NEFA as well as BHB and IGF-1 concentrations (Wathes et al., 2007; Cheng et al., 2015).

The uncoupled GH-IGF-1 axis raises a problem involving the control of gluconeogenesis by GH when "the liver is refractory to GH" (Lucy, 2008), which may cause some health risks: "The consequences of inadequate GHR 1A expression are serious. The liver remains unresponsive to $\mathrm{GH}$ and various GH-dependent processes (including gluconeogenic mechanism) are not initiated. This may predispose the cow to fat liver and ketosis and preclude the normal hepatic mechanism for nutrient partitioning during increased lactation" (Lucy et al., 2001). This concern regarding the uncoupled GH-IGF-1 axis and ketosis has indirectly been confirmed. The infusion of insulin + glucose recouples the GH-IGF-1 axis (Butler et al., 2003; Rhoads et al., 2004), and the treatment of ketotic cows with glucose + insulin reduces NEFA and ketone bodies and raises glucose compared with the treatment of ketotic cows with glucose alone (Sakai et al., 1993). This suggests the stimulation of gluconeogenesis by GH after the recoupling of the GH-IGF-1 axis by glucose + insulin, as has been shown by Butler et al. (2003).

The likely pivotal role of insulin within this complex of uncoupled GH-IGF-1 axis, fat liver, and ketosis can be further deduced from the treatment of cows with a slow-release insulin (SRI). An increasing single dose of SRI at $d 3$ p.p. decreases the percentage increase in liver triglyceride (TG), and on $d 5$, the average liver TG tends to be lower than that in the control (Hayirly et al., 2002). In agreement with these data are the observations of Smith et al. (2009). Prepartum administration of 2,4-thiazolidinedione, a ligand of the peroxisome proliferator-activated receptor-y (PPAR-y), which potentiates the action of peripheral insulin in several species (see reference by Smith et al., 2009), reduces p.p the concentration of NEFA and liver fat content in dairy cows (Smith et al., 2009). Prevention of fatty liver by glucagon is probably mediated by an increase of glucose and insulin and the resulting decrease of NEFA (Nafikov et al., 2006).

The refractory behavior of the liver to GH with consequences for gluconeogenesis is probably worsened by BHB. Ketogenesis depresses glucose synthesis (see Danfær, 1994), hyperketonemia in ewes reduces endogenous glucose production (Schlumbohm and Harmeyer, 2004), and intravenous BHB infusion for $48 \mathrm{~h}$ in cows reduces the glucose concentration in the blood (Zarrin et al., 2013). This antagonism explains the significant negative correlation between glucose and BHB in dairy cows (Harrison et al., 1990) and the reciprocal concentration of high BHB and low glucose in ketotic cows (Li et al., 2012; Du et al., 2018) or of glucose and acetoacetate (Hove, 
1974). This antagonism agrees with the inhibition of glucose synthesis from propionate in vitro by BHB in sheep hepatocytes (Demigne et al., 1986).

The reasons for the BHB effect on glucose synthesis are not clear, but histone lysine can be post-translationally modified by butyrylation or $\beta$-hydroxybutyrylation, and hence, gene expression can be modulated by metabolites such as ketone bodies, as shown in experimental animals (Li et al., 2018b). A growing body of evidence shows that BHB is a signaling metabolite in monogastric animals with effects on energy expenditure, IR, and feeding behavior (Rojas-Morales et al., 2016).

The health risks of NEFA and BHB are not restricted to the uncoupling of the GH-IGF-1 axis and the inhibition of gluconeogenesis because both metabolites have hypophagic effects and decrease DMI (Scharrer, 1999), thereby confirming the negative correlation between BHB and DMI (Lean et al., 1992) and explaining the decline of DMI in cows with clinical ketosis (Baird, 1977, 1982). In addition, increasing evidence suggests that BHB induces hepatocyte adoptosis in dairy cows with fat liver (Tharwat et al., 2012) and add to immunosuppression. BHB reduces bovine neutrophil and bactericide activity against mammary pathogenic $E$. coli (Grinberg et al., 2008).

Genetic background and ketosis: The heritability of ketosis was determined very early by Dohoo et al. (1984) at 0.31 and by van Dorp et al. (1998) at 0.39 . A recent compilation of heritability by Pryce et al. (2016) summarized much lower values. The significant genetic correlations between MY and ketosis support a genetic background for this disease. In heifers of Norwegian cattle, genetic correlations of 0.65 (Simianer et al., 1991) and, in Canadian Holstein cows, of 0.77 (Uribe et al., 1995) have been determined, although lower correlations have been published (Lyons et al., 1991). The genetic background of ketosis is mirrored by data concerning the high heritability of the BHB and NEFA concentrations (0.3-0.4) (Oikonomou et al. (2008b) and of the fat-to-protein ratio (0.3) in milk during early lactation (Buttchereit et al., 2012). Consistent with the correlation between MY and ketosis is the observation regarding a genetic correlation (0.49) between milk BHB $\left(\geq 0.2 \mathrm{mmol} \cdot \mathrm{l}^{-1}\right)$ and the fat-to-protein ratio of milk in Canadian Holsteins (Koeck et al., 2014a).

The genetic correlations can be deduced from the (genetic) homeorhetic priority of milk production, which is relatively uncoupled from DMI $(=\mathrm{NEB})$, and the resulting uncoupling of GH-IGF-axis: high NEFA concentrations, impaired gluconeogenesis in the fat liver, and the production of ketone bodies. Adaptation is overloaded (= ketosis), and milk production proceeds at the expensive of other physiological functions with an accompanying impairment of health.

Ketosis and secondary diseases: The complex interactions and side effects of BHB might explain the greater chances of subclinical ketosis with metritis $\left(\geq 1.4 \mathrm{mmol} \cdot \mathrm{l}^{-1} \mathrm{BHB}\right)$, displacement of the abomasum $\left(\geq 1.2 \mathrm{mmol} \cdot \mathrm{l}^{-1}\right.$ BHB), lameness ( $\geq 1.5 \mathrm{mmol} \cdot \mathrm{l}^{-1}$ BHB) (Suthar et al., 2013), association with impaired fertility (Baird, 1982), early culling (Seifi et al., 2011), and reduced milk production (Duffield et al., 2009). This general interaction between ketosis and diseases has been confirmed by Berge and Vertenten (2014): "Ketosis was associated with significant higher odds of all common fresh cow diseases: metritis, mastitis, displaced abomasum, lameness and gastrointestinal disorders".

A comprehensive meta-analysis by Raboisson et al. (2014) has confirmed the general health risk of subclinical ketosis with reduced milk production and longer calving-to-first-service and calving-to-conception interval. The predisposing effects of BHB concentrations as a health risk have been cautiously analyzed by McArt et al. (2013) with a cut-point of BHB with $0.8 \mathrm{mmol} \cdot \mathrm{l}^{-1}$ before and 1.2-1.4 $\mathrm{mmol} \cdot \mathrm{l}^{-1}$ after parturition and have, among others, been carefully summarized in a wide-ranging review by Overton et al. (2017).

Incidence of ketosis: The high demand of energy with hormonal and metabolic alterations promotes metabolic stress, which is obviously wide spread in high-producing cows throughout the world. The incidence of subclinical ketosis is calculated to be up to $40 \%$ (see review by McArt et al., 2013) and, in European dairy farms, at $39 \%$ based on a milk test for ketones $\geq 100 \mu \mathrm{mol} / 1$ (Berge \& Vertenten, 2014) or $21.8 \%$ with a BHB threshold in blood of $\geq 1.2 \mathrm{mmol} / 1$ (Suthar et al., 2013). The incidence of subclinical ketosis at $72 \%$ is much higher in cows with more than three lactations (threshold $\geq 1.2 \mathrm{mmol} \cdot \mathrm{l}^{-1}$ BHB in blood) (Kaufman et al., 2018) and agrees with the findings of McArt et al. (2013) that advanced parity is a major predictor of hyperketonemia during early lactation. This high incidence in older cows coincidences with the possible net loss of energy with increasing numbers of lactations, MY, and deeper NEB (Coffey et al., 2004) and suggests an exacerbation of ketosis during long-lasting energy shortage and the lack of replenishment within the current lactation. This is in agreement with the increasing decline of BCS p.p. with rising parity (Waltner et al., 1993) and consequently with higher chances of diseases in ketotic cows of parity 2 or more (Berge \& Vertenten, 2014). 
Pathogenesis of ketosis: Taken together, the current data allow an extended explanation of the pathogenesis of ketosis. Selection for higher milk production at insufficient DMI leads to the stepwise uncoupling of the GH-IGF-1 axis (high GH and low insulin, IR, and IGF-1 concentrations, see above), the rapid mobilization of NEFA, and increase of NEFA concentration, fat liver, the augmented hepatic production of BHB, the probable inhibition of gluconeogenesis at increased demand, and low glucose concentrations. The uncoupling of the GH-IGF-1 axis by high NEFA and BHB obviously appears to introduce a "vicious circle" (Du et al., 2018) with further risks of increase of fat liver, ketosis, and secondary diseases (Figure 1).

\section{Vicious Circle of Uncoupling GH - IGF - 1 Axis}

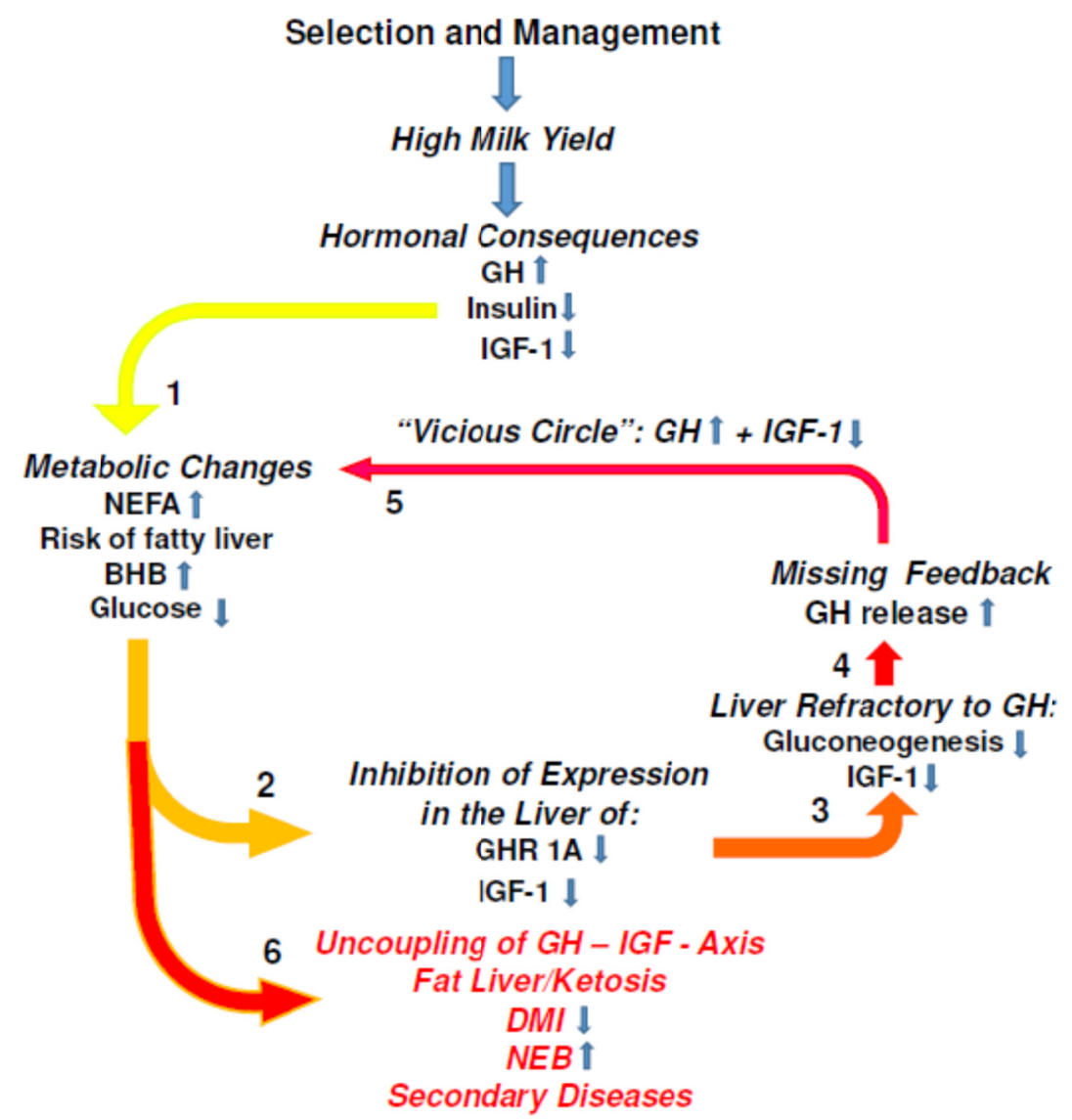

Figure 1. Schematic flow diagram of the pathogenesis of ketosis. The discrepancy between input and output with hormonal alterations such as high GH, low insulin, insulin resistance, and low IGF-1 causes (1) mobilization of NEFA, risk of fat liver with increase of BHB production, impaired gluconeogenesis, and decrease of glucose concentration. The metabolites NEFA and BHB (2) decrease the expression of IGF-1 and GHR 1A in the liver, leading to the liver becoming refratory to GH (3). Gluconeogenesis and IGF-1 synthesis in the liver are further decreased, as is the feedback of IGF-1 on the inhibition of GH release from the pituitary. GH is further increased. These hormonal alterations (5) with metabolic consequences of high NEFA and BHB exacerbate the uncoupling of the GH-IGF-1 axis resulting in the "vicious circle" of ketosis (Du et al., 2018) with reduced DMI and increased NEB and risk of secondary diseases (6)

The relationship between the uncoupling of the GH-IGF-1 axis and the pathogenesis of ketosis in dairy cows is intriguing because this uncoupling is not observed in sows p.p. (Lucy, 2008), and ketosis is not known in pigs.

The homeorhetic priority of milk production together with the genetic disposition of high-producing cows is a challenging adaptation and triggers metabolic disorders and impairs fertility. Ketosis (Baird, 1982) and subclinical BHB early p.p. (Walsh et al., 2007) are correlated with impaired fertility. This negative interaction is corroborated by the genetic correlation between ketosis and cystic ovaries (see review Pryce et al., 2016). 


\subsection{Fertility}

Decline of fertility and reproduction: Impairment of fertility has been the major cause for disease-dependent culling of dairy cows in Germany for many years (BRS, 2019). Butler (2003) and Dobson et al. (2008) have summarized the reciprocal correlation between an increase of MY and the decrease in conception rate during the last few decades. "Management, nutrition, production, and genetics are the main reasons for the decline in fertility in modern dairy cows" (Chagas et al., 2007); this is related to the delayed resumption of ovarian cyclicity p.p., disarranged ovarian activity as a persistent corpus luteum and prolonged luteal phase, low progesterone and estradiol concentrations, reduced estrus behavior, metritis, low oocyte quality, and early embryonic mortality. Possible reasons for these aberrations have been discussed in several reviews and original publications: genetics (Berry et al., 2003; Berry et al., 2016; Hazel et al., 2017; Cai et al., 2019), management (Beever, 2006; Roche, 2006; van Saun \& Sniffen, 2014), nutrition in general (Diskin et al., 2003; Lucy, 2003; Beever, 2006; Roche, 2006; Dann et al., 2006; Chagas et al., 2007; Friggens et al., 2010; van Saun \& Sniffen, 2014; Drackley \& Cardoso, 2014; Rodney et al., 2018), infection and fertility (Sheldon et al., 2009), NEB, health risks, perturbed immune function, and inflammation (Esposito et al., 2014), lipid reserves (Friggens et al., 2003), protein intake and fertility (Butler, 2000; Tamminga, 2006; Lean et al., 2012), protein and urea (Cheng et al., 2015), metabolic status and fertility (Pushpakumara et al., 2003; Wathes, 2012), "mismatch between metabolism and fertility" (Leroy et al., 2008), hormonal changes and fertility (Lucy, 2003; Santos et al., 2016), enhanced clearance of steroids in high-producing cows (Sangsritavong et al., 2002; Wiltbank et al., 2006), decreased progesterone synthetic capacity of lower corpus luteum volume (Moore et al., 2014a), and from a veterinarian point of view, "causes of poor fertility" (Walsh et al., 2011).

Signal cascade of fertility and reproduction: The detrimental effects on fertility occur at each step of the signal cascade of regulation of fertility and pregnancy and include a) the hypothalamus/pituitary and release of gonadotropins, b) blood metabolites and steroid concentrations, c) the ovary with follicular growth and corpus luteum, d) the quality of the oocyte, or e) embryo development, as has been analyzed (a, c, d, e) in a previous review by Webb et al. (1999).

Consequently, various aspects of the signal cascade from hypothalamus/pituitary, ovary, and uterus and from fetal development and (under)nutrition or metabolism have been studied and described: the dominant role of $\mathrm{GnRH}$ in the hypothalamus/pituitary and the release of gonadotropins (HPG axis) (Wade \& Jones, 2004; Schneider, 2004; Clarke, 2014; Hill \& Elias, 2018), the effects of nutrition and metabolic status on circulating hormones such as LH, FSH, estradiol, progesterone, insulin, and IGF-1 and possible effects on pre-ovulatory follicle growth and ovulation (Diskin et al., 2003, Wathes, 2012), the somatotropic axis and follicular growth (Silva et al., 2009; Lucy, 2012), the regulation of the corpus luteum (Wiltbank et al., 2012), the role of glucose for embryonic and fetal development (Lucy et al., 2014), progesterone and early pregnancy (Spencer et al., 2015), prostaglandins and maternal recognition (Arosh et al., 2016), oocyte development and stress (Roth, 2018), embryonic and early fetal loss (Diskin \& Morris, 2008), the role of lipids as regulators of conceptus development (Ribeiro, 2018), and the interaction between metabolic stress and innate immunity and inflammation of the endometrium (Sheldon et al., 2017).

It is not the intention of this overview to summarize, repeat, or emphasize the possible main topics of impaired fertility. The available data will be used for the discussion of the following hypotheses. Does a new pregnancy make sense during a phase of under-nutrition? Is the cow, from a biological point of view, interested in becoming pregnant again during the period of the homeorhetic priority for milk production at a high metabolic load and at insufficient nutrition? If so, how is the interaction between under-nutrition and fertility mediated?

Nutrition and fertility: Wade and Jones (2004) have analyzed the biological relationships between (under)nutrition and fertility (mainly in experimental animals and not in cattle) and concluded that a hierarchy of nutrient allocation occurs at insufficient nutrition:

a) with priority for essential processes such as cell maintenance, circulation, and neural activity,

b) with restriction of reducible processes such as thermoregulation, locomotion, or growth or,

c) with cessation of expendable processes that are not essential for survival such as fat storage or reproduction.

Hence, fertility is directly influenced by under-nutrition (Wade \& Jones, 2004; Schneider, 2004; Clarke, 2014; Hill \& Elias, 2018) and indirectly by the preference for one trait at limited resources (Beilharz et al., 1993), by metabolic stress and downregulation of other traits (Knight et al., 1999), or by the priority of homeorhetic milk production (Bauman \& Currie, 1980). MY should be allocated as an "essential process" according Wade and 
Jones (2004) and has priority despite the prevailing NEB (under-nutrition) and the antagonism between MY and DMI (see above).

These theoretical considerations are confirmed by a growing and overwhelming set of experimental data about interactions between the shortage of nutrients and the impairment of the regulation of fertility and pregnancy. Day et al. (1986) have observed low LH concentrations and pulse frequency in heifers with restricted feed intake. Further, the LH response to $\mathrm{GnrH}$ is lower in animals having a restricted diet. In agreement with these results are the findings of Rutter and Manns (1987) in beef cows p.p.: the reduced availability of glucose by phlorizin treatment causes smaller and fewer large LH pulses in p.p. beef cows. Schillo (1992) has summarized, in a comprehensive review, the interaction between feed restriction and cyclicity in ruminants. Under-nutrition inhibits pulsatile LH secretion by reduced GnrH secretion in the hypothalamus. Metabolites and hormones or oxidizable fuels are suggested as possible mediators between hormones and fertility traits. In accordance with these conclusions are the observations of Canfield and Butler (1990) that "the pulsatile LH secretion is suppressed until the nadir of NEB is reached", and Canfield and Butler (1991) suggest further that the ovaries of cows under NEB are less sensitive to LH. Decreased LH secretion and reduced sensitivity is probably the cause for the positive and linear relationship between the days p.p. until the nadir of NEB and number of days to first ovulation (Beam \& Butler, 1999). The increasing loss of BCS (= deeper nadir of NEB) delays ovulation (Beam $\&$ Butler, 1999) leading to the conclusion "that negative energy balance is the major nutritional link to low fertility in lactating cows" (Butler, 2005). Banos and Coffey (2010) have confirmed these observations and conclusions. The duration and sum of NEB show high genetic correlations between the numbers of days after calving and the first observed estrus.

The correlations mentioned above indicate an interaction between insufficient nutrition, metabolism, and the signal cascade of cyclicity, estrus, and finally pregnancy. The missing interface between these parameters was discussed by Canfield and Butler as early as 1990; they suggested the involvement of the hypothalamus or higher neuroendocrine control centers and proposes that the energy status is conveyed to the brain by NEFA. Indeed, the availability of oxidizable fuels, glucose, and NEFA is the "transmitter" that is detected by peripheral and central metabolic fuel sensors (Wade \& Jones, 2004; Schneider, 2004).

Metabolic sensor and oxidizable fuels: The central sensor is located in the area postrema (AP) in the floor of the fourth ventricle in the hindbrain (Wade \& Jones, 2004). Corresponding glucose-sensing neurons are arrayed in the brainstem and the hypothalamus (Levin, 2006). The information regarding oxidizable fuels at the fuel detector in the hindbrain is relayed to the GnRH neurons in the forebrain (details of transmitter and neurons see Wade \& Jones, 2004; Schneider, 2004; Clarke, 2014; Hill \& Elias, 2018). GnRH is the driver of reproduction, is secreted in a pulsatile manner from the preoptic area of the hypothalamus into the hypophysial portal system, and regulates the synthesis and pulsatile release of LH from the anterior pituitary (Clarke, 2014).

A key role as oxidizable fuel is obviously exerted by glucose at the central sensor. Glucoprivation of this fuel sensor suppresses LH pulses in rat (Nagatani et al., 1996; Murahashi et al., 1996) and in sheep occurs peripheral to the GnRH neuron (Bucholtz et al., 1996; Ohkura et al., 2000). Blood glucose concentration is reduced in cross-bred heifers at restricted feed intake with corresponding effects on LH release (Yelich et al., 1996). The LH response is obviously related to GnRH release. Growth restriction in young sheep reduces the frequency of GnRH release, and not all GnRH pulses stimulate the pulsatile secretion of LH (l'Anson et al., 2000). This confirms the data of Day et al. (1986) showing a decreased LH response to GnrH infusion in feed-restricted heifers (see above). The possible downstream effects are predictable and agree with the conclusion of Diskin et al. (2003) that NEB "adversely affects the size and the ovulatory fate of the dominant follicle". Concomitantly, the duration of estrus decreases with increasing MY (Wiltbank et al., 2006).

The decisive role of glucose on fertility was shown decades ago in cows by McClure (1968). The conception rate of cows curvilinearly increases with increasing glucose concentration in the blood and agrees with observations of Harrison et al. (1990) who found that, in cows, a low blood glucose concentration during week 1 p.p. is negatively correlated with the number of days to conception. Adverse effects of a low glucose concentration early p.p. on conception have been confirmed since then (Reist et al., 2003; Oikonomou et al., 2008a; Garverick et al., 2013; Cardoso et al., 2013), and vice versa, an increased ratio between glucose and BHB has been correlated with the higher probability of estrous expression at first ovulation (Westwood et al., 2002), and a higher blood glucose concentration is positively associated with pregnancy after first insemination, including the production of heavier fetuses (Green et al., 2012). Lucy et al. (2014) and Dupont et al. (2014) have summarized the available data on glucose and fertility in comprehensive reviews and have emphasized the outstanding peripheral role of glucose for ovarian cyclicity and luteal function, immune function and uterus health, pregnancy, and fetal development. 
NEFA are also oxidizable fuels, and evidence exists with regard to the effect of lipoprivation on LH pulses in hamsters, but is uncertain in other species (Wade \& Jones, 2004), and corresponding data with respect to NEFA are missing in cattle. In sheep, intravenous NEFA infusion does not change luteinizing hormone secretion (Estienne et al., 1989). By contrast, "increased serum NEFA and BHB concentrations had a detrimental effect on reproductive performance" (Opsina et al., 2010) with a NEFA threshold of $\geq 0.27 \mathrm{mmol} \cdot \mathrm{l}^{-1}$ prepartum and $\geq 0.72$ $\mathrm{mmol} \cdot \mathrm{l}^{-1}$ p.p. and a p.p. BHB value of $\geq 1.4 \mathrm{mmol} \cdot \mathrm{l}^{-1}$. This corroborates the data of Walsh et al. (2007): the predicted probability of pregnancy linearly decreases with increasing BHB concentrations in week 2 p.p. Similarly, Garverick et al. (2013) conclude that "postpartum monitoring NEFA and glucose could theoretically be used to identify cows at risk for infertility". The correlation with NEFA has been validated by Ribeiro et al. (2013). An elevated NEFA concentration reduces P/AI on d 65 after AI. The p.p. threshold of $\geq 0.72 \mathrm{mmol} \cdot \mathrm{l}^{-1}$ (Opsina et al., 2010) has been confirmed by Ribeiro (2018). Cows with NEFA concentrations $\geq 0.7 \mathrm{mmol} \cdot \mathrm{l}^{-1}$ during the first 2 weeks p.p. have reduced pregnancy after AI.

Previous in vitro studies (Jorritsma et al., 2004; Leroy et al., 2005, 2006) suggest a possible explanation. Jorritsma et al. (2004) have observed a negative effect of NEFA on the proliferation of granulosa cells, and fertilization and embryonic development of cumulus-oocyte-complexes are reduced by NEFA. Leroy et al. have studied the effect of NEFA (2005) and BHB and glucose (2006) on the development of bovine oocytes. NEFA and BHB during oocyte incubation have negative effects on oocyte maturation. The influence of BHB is more pronounced at a low glucose concentration. NEFA concentrations reflect NEB (Herdt, 2000; Urdl et al., 2015), and based on current knowledge, NEFA and BHB have primarily peripheral effects during the development of oocytes. Furthermore, an "impaired uterine environment" (during NEB and high NEFA, the author) also contribute to subfertility" (Ribeiro, 2018).

Metabolic hormones and fertility: The interaction between nutrition and fertility is not restricted to oxidizable metabolites and their possible effects on central or peripheral sensors. The concentrations of NEFA, BHB, and glucose reflect the changes of GH, insulin, IR, and IGF-1, and the effects of the hormones GH, insulin, and IGF-1 on the signal cascade of fertility regulation have previously been described (Beam \& Butler, 1999; Roche et al., 2000; Adam et al., 2000; Lucy, 2012; Wathes, 2012; Kawashima et al., 2012, Bollwein et al., 2014). The hormonal changes of increased GH, low insulin, IR, and low IGF-1 are the framework of regulation of metabolism, mobilization, and partitioning and determine the homeorhetic priority of high milk production. Undoubtedly, these hormones and the usual hormonal combinations (and the resulting concentrations of NEFA, $\mathrm{BHB}$, and glucose, see above) have effects on reproduction.

The somatotropic axis includes GH and IGF-1 (see part 1). The possible role of GH and IGF-1 on follicular growth has been reviewed by Silva et al. (2009) and by Lucy (2012) who concludes that the effect of GH is mainly indirect via metabolism and the control of IGF-1 by GHR 1A in the liver. The role of IGF-1 has been outlined in detail by Velasquez et al. (2008), Wathes (2012), and Kawashima et al. (2012). mRNAs for IGF-1 have been detected in bovine follicles and luteal cells, and IGF-1 stimulates the proliferation and steroid-genesis in granulosa cells (for details and references, see Velasquez et al., 2008; Wathes, 2012; Kawashima et al., 2012). Consequently, cows with lower IGF-1 concentrations have significantly lower progesterone concentrations (Pushpakumara et al., 2002), and Beam and Butler (1999) have demonstrated a significant linear correlation between IGF-1 and estradiol concentrations. Further, in in vitro studies, the early development of the bovine blastocyst is influenced by IGF-1 (Byrne et al., 2002), which possibly acts in the oviduct (Pushpakumara et al., 2002) and in the uterus by influencing secretion and embryo growth (Velasques et al., 2008). The influence of IGF-1 is not limited to the periphery. "An intrapituitary IGF system exists in sheep and the present results are consistent with an endocrine role of the IGF-1 in nutritional modulation of LH secretion" (Adam et al., 2000). Zulu et al. (2002) have analyzed the role of IGF-1 in bovine reproduction and conclude that "IGF-1 is therefore one of the long sought factors that signal nutritional status to the reproductive axis", and that "IGF-1 plays a pivotal role in cattle fertility, acting as a monitoring signal ... when nutritional conditions for successful reproduction are reached" (Velasquez et al., 2008).

The multiple modulation of the signal cascade by IGF-1 from the pituitary to ovary and to uterus might explain the relationship between IGF-1 and fertility in cows (Taylor et al., 2004). The latter authors observed that the lowest IGF-1 concentration p.p. in multiparous cows was correlated with the highest milk production, and that cows with the lowest IGF-1 concentration p.p. failed to become pregnant despite services. Gobikrushanth et al. (2018) studied in more detail the association between serum IGF-1 and fertility. Cyclic multiparous cows had a greater serum IGF-1 concentration during the first week p.p. compared with acyclic cows, whereas primiparous and multiparous cows with a high serum IGF-1 concentration had a greater P/AI than those with low IGF-1. The optimum serum IGF-1 thresholds predictive for P/AI were $85.0 \mathrm{ng} / \mathrm{mL}$ and $31.0 \mathrm{ng} / \mathrm{mL}$ for primiparous and 
multiparous cows, respectively. Correspondingly, cows with a high genetic merit for fertility had greater IGF-1 concentrations in their blood (Moore et al., 2014b).

Insulin is indirectly involved in the somatotropic axis, because it mediates the expression of GHR $1 \mathrm{~A}$ in the liver (Butler et al., 2003), and hence, insulin and IGF-1 are positively correlated (Wathes et al., 2007). Furthermore, insulin has effects on the HPG axis including the ovary with a potential influence on fertility (Beam and Butler, 1999). Despite these versatile impacts, insulin measurements do not improve predictions of fertility (Wathes et al., 2007). Wathes (2012) has analyzed this topic and suggests the diet-dependent variation of insulin concentration and, in particular, the regulation of insulin receptors as possible reasons for the missing correlation. Despite this restriction, insulin is well known to regulate ovarian activity in woman and experimental animals (Porestky et al., 1999), and cows with a good genetic merit for fertility tend to have a greater insulin concentration (Moore et al., 2014b).

The numerous direct or indirect relationships between nutrient-dependent hormones or metabolites and fertility reveal the outstanding importance of the sufficient availability of nutrients for fertility and are in agreement with the data of Oikonomou et al. (2008a). BCS, BHB, NEFA, and glucose during early lactation as parameters of energy metabolism have the highest genetic correlation with reproductive performance. Malnourishment at high demand for MY and reduced intake predispose to reduced fertility, and this negative modulation can be observed at the fuel sensor in the hindbrain, hypothalamus, pituitary, ovary, oviduct, and uterus and during early pregnancy.

The extensive set of data compiled above appears to offers a causal explanation of the impairment of fertility within the signal cascade of cyclicity regulation including pregnancy. Unfortunately, the list of hormones and metabolites sometime change before parturition, regularly immediately after parturition, and hence far before the cows fail to conceive between 60 and $100 \mathrm{~d}$ pp.p. This gap prompted Britt in 1992 to propose a hypothesis about possible effects on the development of a resting primordial follicle until ovulation, which requires approximately 100 days. If the growing follicle is exposed to adverse conditions during this period, gene expression might be affected (Britt, 1992) with delayed consequences for ovulation, oocyte quality, or pregnancy. Interestingly, Britt (1992) considered NEB as an adverse condition that somehow "imprinted" upon follicle development. This hypothesis was used to explain retrospectively the difference in fertility between dairy cows with a high and low change of BCS early p.p. (Britt, 1992). It confirmed the hypothesis that "events that occur early postpartum influence fertility much later" (Britt, 1992). The modulation of "gene expression" of the follicle resulting in impaired or altered development was, at that time, a hypothesis to explain early cause and later effect (Britt, 1992). The delay remains, to the author's knowledge, miraculous, but some suggestions can be made.

Gene expression can be influenced by epigenetic gene regulation, which includes a) covalent DNA modification, b) covalent posttranslational modifications made to the tails of histone proteins, and c) noncoding RNA (Ideraabdullah \& Zeisel, 2018). One of the most intriguing aspects is the acetylation of the histone proteins by the metabolites butyrate (butyrylation) or BHB ( $\beta$-hydroxbutyrylation) as driven by ketogenesis under low nutrient conditions (Xie et al., 2016). The binding of metabolites to the tail of histones facilitates the accessibility of DNA, which is now more permissive for transcription, and contributes to the regulation of DNA-based processes ("gene expression"). The reaction is catalyzed by the histone acetyltransferase (HAT) and the release by histone deacetylase (HADAC) (Narita et al., 2019), which can be inhibited by butyrate and BHB (Shimanzu et al., 2013), thereby supporting the evidence that BHB is a signaling metabolite (up to now in monogastric animals, the author) with effects on energy expenditure, IR, and feeding behavior (Rojas-Morales et al., 2016). Hence, undoubtedly, metabolites have wide-spread epigenetic activity and consequences for metabolism (Li et al., 2018b; Xie et al., 2016), metabolic syndrome, and NAFLD (Ideraabdullah \& Zeisel, 2018). Unfortunately, to the knowledge of the above authors, corresponding results concerning fertility are still missing, but the interaction between metabolites and the epigenetic modulation of gene expression within the signal cascade of cyclicity and pregnancy offers experimental support.

Despite the uncertainty between early causes and later effects, each level of signal cascade can be modulated (see above), and for future discussion of this topic, a hierarchy of impact is proposed: The higher possible influences in the signal cascade denote the consequences. Glucose and IGF-1 appear to be predominant factors within this arbitrary classification. Glucoprivation at the central fuel sensor in the hindbrain inhibits GnrH release and consequently LH pulses (Wade \& Jones, 2004; Schneider, 2004; Clark, 2014), and IGF-1 modulates LH release in the pituitary (Adam et al., 2000) with the known peripheral effects (see above). Glucose and IGF-1 are decreased p.p., cooperate in the central nervous system, and intensify the inhibition of pulsatile LH release. 
In addition to the effects at the top of the regulation cascade, the possible impact of the myriad effects downstream of GnrH and LH release appear to the author as possible "intervention sites". If the local hormonal and metabolic circumstances are not optimal, possible steps for follicle growth, steroid synthesis, estrous behavior, ovulation, or embryo development are downregulated. Hence, the whole signal cascade resembles the combination of a central control hierarchy with peripheral subsidiarity, and suggest the compound embedment of the regulation of reproduction with the goal of the optimal regulation of cyclicity and successful pregnancy or simply of avoiding malfunction.

This system allows flexible adaptation to metabolic and hormonal changes. These biological responses should above all be regarded as positive reactions, because pregnancy during under-nutrition possibly challenges the health of the cows and the development of the embryo. Hence, the possible modulation of reproduction by nutrition should be considered as a biological capability to adjust to various inputs during an optimal window for the next pregnancy. The impairment or constraint of fertility is, in this sense, not a disease but a normal transient period: "The cow knows better". Leroy et al. (2008) have discussed this problem in detail as a "mismatch between metabolism and fertility". The nutrient prioritization of the cows favors milk production over fertility (Leroy et al., 2008) or, again, endorses homeorhesis. However, this general biological background can be disrupted, go out of control, and promote, for instance, the pathogenesis of cystic ovaries with an altered HPG axis and intraovarian components (Ortega et al., 2015).

\section{Interdependencies Between NEB, Ketosis, and Fertiliy}

The genetic antagonism between increasing MY and DMI p.p. is a challenge for a high-producing cow with multiplied demands and should be critically contemplated because the deep and long-lasting NEB over two months, with a deficit of $1500 \mathrm{MJ}_{\mathrm{NEL}}$ or more, represents chronic under-nutrition (Vernon, 1998) and a distinct health risk, despite the original biological background. Presumably for this reason, Roche et al. (2009) have stated "It is perfectly natural for cows to lose BCS (= NEB, the author) in early lactation (homeorhesis), and this loss cannot be eliminated by improved feeding". Of course, the capability for compensating an energy deficit by mobilization and BCS loss is natural with an important biological intention (see part 1), and the possible deficit is of minor impact at MY for the nutrition of one calf (Hart et al., 1975). The congenital biological predisposition for a slight NEB and a moderate rate of mobilization has been involuntary used to fill the increasing deficit with increasing MY. Hence, the current extent and duration of NEB is, from the author's point of view, not "natural" and leads to pathophysiological consequences. The hormonal background includes high GH, low insulin, IR, and low IGF-1, finally resulting in the uncoupling of the GH-IGF-1 axis and metabolic changes such as increased NEFA, BHB, and low glucose (Table 1). These alterations challenge health and predispose to fat liver and ketosis (Table 1).

A second predisposition with health risk is the correlation between MY $(\approx$ NEB $)$ and impairment of fertility (Table 1). The manifold downregulation at the various levels of the signal cascade of regulation of fertility and pregnancy at impaired nutrition primarily involves a biological response.

Unfortunately, the hormonal and metabolic conditions surrounding high MY $(\approx$ NEB $)$ are the major reasons of fat liver, ketosis, and disturbed fertility, and this common etiology explains the correlation between these two diseases (Baird, 1982; Walsh et al., 2007). 
Table 1. Compilation of hormonal and metabolic changes that enable and accompany high MY $(\approx$ NEB $)$ and their direct or indirect influences on the risk of fat liver and ketosis or of impairment of fertility in high-producing dairy cows

\begin{tabular}{lll}
\hline Hormonal and metabolic changes at high MY & Risk of fat liver and ketosis & Impairment of fertility \\
\hline GH $\uparrow$ & + & $(+)$ \\
Insulin $\downarrow$ & + & $(+)$ \\
Insulin Resistance (IR) & + & $(+)$ \\
IGF-1 $\downarrow$ & + & + \\
Uncoupled GH-IGF-1 axis & + & $(+)$ \\
Glucose $\downarrow$ & + & + \\
NEFA $\uparrow$ & + & + \\
BHB $\uparrow$ & + & + \\
NEB $\uparrow$ & + & + \\
Risk of Inflammation & + & + \\
Immunosuppression & - & +
\end{tabular}

Note. $\uparrow:$ increase; $\downarrow$ : decrease; +: increasing risk of ketosis or impairment of fertility; $(+)$ : uncertain; -: not known.

\section{Suggestions and Conclusions}

Homeorhesis: Homeorhesis is a term for the regulation of milk production during early lactation, although the major focus of regulation changes during the lactation period. After parturition, milk production has the absolute homeorhetic priority. With decreasing milk production after peak MY and increasing DMI, a zero energy balance is achieved. At this point, lost body weight is compensated for, and during the rest of lactation and the dry-off period, nutrients are used for the mother and the growing calf (Oldham, 1984). Below, this term is divided into phase 1 of homeorhesis from parturition until the end of NEB followed by phase 2 until the end of pregnancy.

An important conversion of the priority of nutrient partitioning occurs during these two phases. During phase 1, the homeorhetic priority of milk production occurs at insufficient DMI, and feed restriction does not influence MY (McNamara \& Hillers, 1986). However, restricted feed intake during phase 2 (after the period of NEB) causes a reduction of MY (Gross \& Bruckmaier, 2015), which indicates that the new priority is now for the mother and pregnancy. Remarkably, the nutrition of the calves is ensured in both phases: homeorhesis directly ensures the nutrition of calf 1 in phase 1 and of calf 2 indirectly in phase 2.

Metabolic stress: Metabolic stress is an often and broadly used term to describe the metabolic changes and challenges during early lactation. This term should thus only be used in the sense of Knight et al. (1999) with the meaning "that amount of metabolic load (or metabolic burden) which cannot be sustained (or tolerated), such that some energetic processes (which could include those maintaining general health) must be down regulated". A corresponding conclusion has been made by Sordillo and Mavangira (2014): "A major underlying factor responsible for the development of transition cow disorders is metabolic stress, which occurs when cows fail to adapt physiologically to an increase of nutrient requirement needed for parturition and the onset of copious milk synthesis and secretion".

An indication of failing adaptation and metabolic stress is the rate of mobilization above the actual requirement (Sordillo \& Raphael, 2013); the increase of NEFA causes IR, fat liver, BHB production, ketosis, and secondary diseases. Two imbalances occur at the same time. DMI is lower than requirement, whereas the mobilization of NEFA is above requirement. Growing evidence indicates that the imbalances increase with MY and are probably the major health risk, not MY per se. Mobilization according the requirement and steady state at low NEFA would be a desired ambition as a future goal of selection and management.

Evidence is accumulating that metabolic stress includes inflammation (Trevisi et al., 2012; Sordillo \& Raphael, 2013) and oxidative stress (Sordillo \& Aitken, 2009). Vice versa, inflammation has an impact on metabolism. Infusion of the proinflammatory cytokine TNF- $\alpha$ in lactating dairy cows causes an increase of NEFA (Kushibiki et al., 2000), a significant increase of TAG in the liver (Bradford et al., 2009), a decrease of transcription of enzymes involved in gluconeogenesis (Bradford et al., 2009), and a decrease of insulin sensitivity (Kushibiki et al., 2000). Hence, metabolic stress involves the risk of subclinical or clinical production diseases including inflammation, and these possible hazards should be mentioned when the term "metabolic stress" is applied 
NEB and replenishment: The loss of body reserves during early lactation is generally assumed to be replenished before the next parturition. Increasing evidence suggests that this compensation does not occur in all cases (Waltner et al., 1993; Coffey et al., 2004). A NEB throughout an entire lactation has been monitored by Hurley et al. (2018) in cows reared in a non-intense production system and selected for lower residual energy intake (REI). In agreement, Miglior et al. (2017) have found a negative genetic correlation "between gross feed efficiency and energy balance (from- 0.73 to -0.99 ) indicating that selection for more efficient cows would favour a lower energy status". These findings shed further light on efforts to select cows with higher feed efficiency in order to reduce feed costs, which are the highest cost factor of milk production. If high feed efficiency means that NEB occurs without compensation by replenishment, milk production is maintained at the expense of body reserves. A lack of replenishment should be judged as milk production with abrasion, and "this gradual erosion of body energy stores may be of concern of health, welfare, and profitability viewpoints" (Coffey et al., 2004).

Relief of NEB: The NEB of early lactation is a serious health risk. The insufficient DMI at the onset of lactation (Karacaören et al., 2006; Liinamo et al., 2012; Manzanilla-Pech et al., 2014; Krattenmacher et al., 2019) and the primarily partitioning of nutrients to the mammary gland in high-producing cows (Agnes \& Yan, 2000) make the limitation of the NEB with a further increase of MY unlikely, despite manifold efforts of the periparturient nutritional management (see above). Hence, Lacasse et al. (2018) have discussed the possibility of reducing the gap by a decrease of output: a) inhibition of milk fat synthesis, b) prepartum milking, c) once-a-day milking, d) incomplete milking, or e) inhibition of lactating signal. They propose, based on current knowledge, incomplete milking for 5 or 6 days p.p. as a tool to reduce the metabolic load or even stress. This would provide load removal at the present but is not a solution for the future if the selection for higher MY continues.

Production and reproduction: The reciprocal relationship between MY $(\approx$ NEB) and fertility (Butler, 2003; Dobson et al., 2008) is usually considered as "antagonism". However, the downregulation of the whole signal cascade of regulation of fertility and pregnancy should be assessed as a biological reaction to insufficient nutrition: "Biologically, it is a predictable response, part of a normal function" (Knight et al., 1999). Any intervention for possible improvement has limitations under these circumstances. Non-observance of these interactions might explain the low conception rate and early embryo death in dairy cows, particularly if hormones (GnrH, prostaglandin) and consecutive AI are applied according to a fixed time scale regardless of energy status or BCS.

Lucy (2001) has published an excellent review with the title "Reproductive loss in high-producing cows: Where will it end?" This urgent question is still valid, because the improved understanding of cyclicity and pregnancy, the more accurate diagnosis by ultrasound, and the application of synchronization programs does not and can hardly lead to any ameliorating improvements without the integration of biological mechanisms.

Separate disease or syndrome? The relationships between production and health risks have been debated for decades (Ott, 1996; Rauw et al., 1998; Knaus, 2009; Ingvartsen, 2006: Oltenacu \& Broom, 2010). The underlying under-nutrition with maladaptation and the downregulation of traits that maintain general health (Knight et al., 1999) can be correlated with numerous diseases. Previously, the diseases have been examined and studied primarily as separate events. Studies restricted to one topic will indeed lead to a better understanding of physiological, biochemical, endocrinological, or immunological sequences but have limitations if the pathogenesis of the topic is not embedded into the complex of metabolic stress, inflammation, and immunosuppression. An approach for a better understanding of this complex has been proposed by Sordillo and Mavangira (2014), namely that "a link may exist between metabolic and immune pathways during times of altered nutrient metabolism that can increase the risk of diseases" and suggests a possible common etiology, at least for some of the production diseases. The possible interdependencies are cognizable by the positive genetic correlations of metabolic diseases with other diseases (Pryce et al., 2016; Heringstad et al., 2007). For instance, the strong genetic correlation between ketosis and displaced abomasum (Pryce et al., 2016). Heringstad et al. (2007) has shown that selection against mastitis causes correlated selection responses to other diseases, thereby suggesting a potential common etiology.

As a first step, our knowledge of physiology, biochemistry, immunology, nutrition, veterinary medicine, animal husbandry, and the possible pathophysiological changes and diseases during transition should be summarized and pooled in order to discern possible interactions. The complexity of interactions as implied by Sordillo and Mavangira (2014) should be further studied by an approach considering production diseases as a complex under a common umbrella of "hormonal and metabolic challenges, inflammation, and immunosuppression". This will probably raise the "chicken and egg" issue, but suggestions for solving one problem in isolation without consideration of the whole complex have obvious limitations. 
Management: Proper management, including all environmental factors, do indeed determine the success of a dairy herd production and health. However, the genetic disposition to various health risks in high-producing cows remains, and good management can reduce or perhaps even obviate these risks. Vice versa, insufficient management will exacerbate these risks and increase the incidence of production diseases (Figure 2).

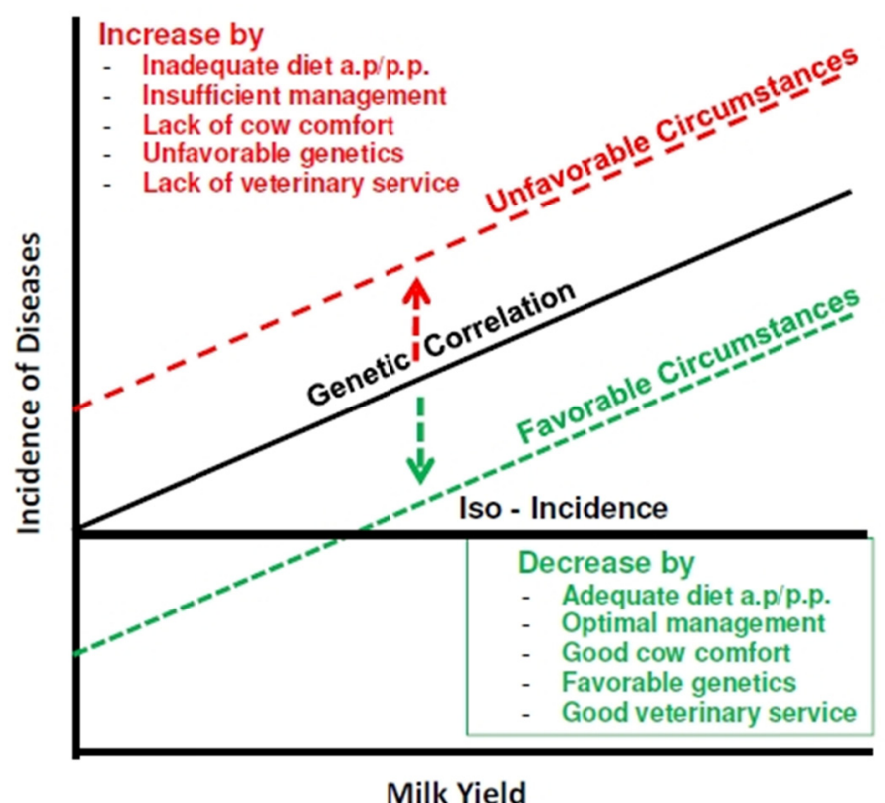

Figure 2. Scheme of correlation (possibly not linear) between milk yield $(\approx$ NEB) and incidence of diseases. This relationship exhibits wide variation, and the incidence of diseases depends on the individual circumstances and might even be absent (iso-incidence). (Modified from Martens, 2016)

Figure 2 highlights the dominant impact of management and might explain the controversy seen in the literature. Fleischer et al. (2001) have demonstrated an exponential increase of various diseases with raising MY, but this is absent in the study of Wangler and Sanftleben (2007). The possible health risks are probably compensated by proper management and confirm the allocation theory of Beilharz et al. (1993). Selection for one trait is possible with no risk for fitness at increased resources and allocation for all traits. However, the primary obligation of optimal management or of good veterinary service does not involve compensation for the genetic disposition of health risks. Further, the major relevance of good management does not eliminate genetic disposition.

An analysis of the etiology of production diseases should therefore distinguish between the cause (genetic disposition) and effects of management. Unfortunately, the differentiation between cause and effect is difficult in practice (except for severe failures of management). However, most of the diseases in dairy cows are observed within the first month p.p. (Carvalho et al., 2019) and therefore during NEB and in association with the corresponding metabolic stress that occur during milk production. The high incidence of subclinical ketosis during early lactation, its heritability (Dohoo et al., 1984; van Dorp et al., 1998), and the genetic correlation between MY and ketosis (Simianer et al., 1991; Uribe et al., 1995) support this conclusion. Hence, genetic disposition is suggested to be the dominant player in the pathogenesis of diseases during this period.

Breeding index: During most of the last century, the primary selection traits for dairy cows were higher production and conformation (for details, see Miglior et al., 2017). This has fundamentally changed during last decades. In 1978, the total merit index (TMI) with balanced breeding goals was introduced for the selection of Norwegian Reds and led to the genetic improvement of production, fertility, and health (https://www.norwegianred.com/Start/Norwegian-Red/about-norwegian-red/Norwegian-Red-Total-Merit-Index/). The implementation of the additional traits was possible, because corresponding data had been available since 1975 from the national health recording system in Norway. This integration has resulted in a significant reduction of clinical mastitis in Norwegian Red cows (Heringstad et al., 2000; Heringstad \& Østerås, 2013). Mastitis resistance in the TMI has been frequently adopted by other Scandinavian countries: Finland and Sweden in 1983 and Denmark in 1990 (Heringstad et al., 2000). 
Since that time, TMIs have been adopted by many countries (Miglior et al., 2005; Brade, 2018). Miglior et al. (2005) analyzed the selection index from 15 countries and determined, on average, values for production of $59.5 \%$, for durability of $28.0 \%$, and for health of $12.5 \%$. Large variation was observed if the emphasis was on production. Brade (2018) confirmed this variation. Production accounted for $26 \%$ in the Netherlands and for $74 \%$ in Japan in 2017. Various sub-indices such as fertility, calving performance, somatic cell count, longevity (length of productive life), workability, and claw and udder health are included in TMI.

A significant shift in animal breeding occurred with the implementation of genomic selection in the United States, Great Britain, Ireland, New Zealand, Australia, the Netherlands, France, the Scandinavian countries, and Germany (Silva et al., 2014). Huge numbers of genomics markers of the livestock genome (single nucleotide polymorphisms-SNP) are available and, for instance, have been demonstrated for production traits such as lactation curve, milk, fat, and protein (Oliveira et al., 2019) and various health traits such as displaced abomasum (Zerbin et al., 2015; Lehner et al., 2018), cystic ovaries, displaced abomasum, ketosis, lameness, mastitis, metritis, retained placenta (Parker Gaddis et al., 2014), mastitis, metritis, retained placenta, displaced abomasum, ketosis, and lameness, (Vukasinovic et al., 2017), association between reproductive performance and serum IGF-1 (Gobikrushanth et al., 2018), ketosis (Parker Gaddis et al., 2018; Kroezen et al., 2018), and somatic cell score (Oliveira et al., 2019). As a consequence, Zoetis Genetic offered, for the first time, an evaluation for wellness traits of Holsteins.

Furthermore, the incorporation of future possible traits such as feed efficiency, immune response, or resistance to infections, and of environmentally friendly animals with less waste and lower greenhouse gases production are being considered (Weller et al., 2017; Miglior et al., 2017), as are the inclusion of data from sensors as a part of precise farming and from mid-infrared analyses (for references, see review Pryce et al., 2016). These new technologies and, indeed, broad extended knowledge are promising and will hopefully integrate the challenge of antagonism between MY and DMI as recently discussed by Krattenmacher et al. (2019).

Conclusions: High-producing cows pass p.p. through a period of NEB. The extent and duration of this under-nutrition has been changed dramatically during the last 3 to 4 decades and can hardly be considered as "natural". Successful adaptation in the sense of "having control of mental and bodily stability" (Fraser \& Broom, 1990) and of "the physiological capability to respond properly, and thus maintain homeostasis" (Siegel, 1995) appears to be impossible in many cases. The consequences are well known: the incidences of fresh cow or production diseases and early death and the premature culling rate are high.

In the past and even today, health risks and diseases have been and are being primarily studied and treated as separate events. In spite of this better knowledge, no relief or improvements in fertility and pregnancy or in mastitis or lameness are apparent. For instance, German data show that the culling rate attributable to lameness has increased over time (Vereinigte Informationssysteme Tierhaltung-vit, 2016), and "no studies have reported a reduction in the prevalence of lameness over the last 20 years" (Heringstad et al., 2018). The incidence of clinical mastitis in the USA increased from 13\% in 1996 (USDA, 1996) to 25\% in 2016 (USDA, 2016). Further, the annual incidence risk of the mortality of cows has been described in a meta-analysis over 25 years: an increase from some $2 \%$ in the 1980 s to $6-8 \%$ in 2008 or by $2 \%$ per decade has occurred (Compton et al., 2017). This observation hardly supports a general mitigation of health risks, although the remarkable decrease of mastitis in the Norwegian Red (Heringstad \& Østerås, 2013) and the GWS (genome-wide selection) and genetic selection are promising aspects for the future.

The myriad studies of separate events have improved our knowledge, and in the current reviews (part $1+2$ ), these data have been used in an attempt to create a synopsis between the physiology of homeorhesis, its changes by selection and management, high MY, broad NEB with hormonal and metabolic changes, ketosis, and fertility by means of an approach to disclose dependencies and causal sequences. The possible convergence should be extended by the addition of further topics to achieve a better understanding of the whole complexity. The integration of immunology, endocrinology (metabolism and fertility), biochemistry, physiology, nutrition, veterinary medicine, and animal husbandry needs to be deepened.

The current breeding indices should encompass further health traits having a predominant emphasis and urgency, including parameters of energy metabolism (metabolites and hormones, the balance of nutrients) for sustainable breeding goals and a long-life cycle of dairy cattle production. The negative or minutely positive genetic correlation between MY and DMI during early lactation with the resulting NEB is an underlying burden for production and health in current breeding indices. With other words: "Genetic selection for high-producing healthy cows should reverse current trends and create a future cow that can transition well and produce 
successfully in high metabolic environment" (Lucy, 2016). Impaired fertility and reproduction under these conditions is primarily a physiological reaction, not a disease, and requires our special attention.

\section{Acknowledgements}

The study was supported by the Margarete-Markus-Charity and the Bundesministerium für Bildung, Wissenschaft und Forschung. The author wish to acknowledge with gratitude the reading and suggestions of W. Brade, H. Bostedt, L. Gruber and S. Leonhard-Marek.

\section{References}

Abuajamiehn, M., Kvidera, S., Fernandez, M., Nayeri, A., Upah, N., Nolan, E., \& Baumgard, L. (2016). Inflammatory biomarkers are associated with ketosis in periparturient Holstein cows. Research in Veterinary Science, 109, 81-85. https://doi.org/10.1016/j.rvsc.2016.09.015

Adam, C., Gadd, T., Findlay, P., \& Wathes, D. (2000). IGF-I stimulation of luteinizing hormone secretion and expression of mRNAs of IGFs, IGF receptors and IGFBPs in the ovine pituitary gland. Journal of Endocrinology, 166, 247-254. https://doi.org/10.1677

Agnes, R., \& Yan, T. (2000). Impact of recent research on energy feeding system for dairy cattle. Livestock Production Science, 66, 197-215. https://doi.org/10.1016/S0301-6226(00)00161-5

Ametaj, B. (2005). A new understanding of the causes of fatty liver in dairy cows. Advances in Dairy Technology, 17, 97-112.

Arosh, J., Banu, S., \& McCracken, J. (2016). Novel concepts on the role of prostaglandins on luteal maintenance and maternal recognition and establishment of pregnancy in ruminants. Journal of Dairy Science, 99, 5926-5940. https://doi.org/10.3168/jds.2015-10335

Bach, K., Barbano, D., \& McArt, J. (2019). Association of mi-infrared-predicted milk and blood constituents with early-lactation disease, removal, and production outcomes in Holstein cows. Journal of Dairy Science, 102, 10129-1039. https://doi.org/10.3168/jds.2019-16926

Baird, G. (1977). Aspects of ruminant intermediary metabolism in relation to ketosis. Biochemical Society Transactions, 5, 819-827. https://doi.org/10.1042/bst0050819

Baird, G. (1981). Lactation, pregnancy and metabolic disorders in the ruminant. Proceedings of the Nutrition Society, 40, 115-120. https://doi.org/10.1079/pns19810016

Baird, G. (1982). Primary ketosis in the high-producing dairy cow: Clinical and subclinical disorders, treatment, prevention, and outlook. Journal of Dairy Science, 65, 1-10. https://doi.org/10.3168/jds.s0022-0302(82) 82146-2

Banos, G., \& Coffey, M. (2010). Genetic association between body energy measured throughout lactation and fertility in cattle. Animal, 4, 189-199. https://doi.org/10.1017/S1751731109991182

Barclay, J., Nelson, C., Ishikawa, M., Murray, L., Kerr, L., McPhee, T., Powell, E., \& Waters, M. (2011). GH-dependent STAT5 signaling plays an important role in hepatic lipid metabolism. Endocrinology, 152, 181-92. https://doi.org/10.1210/en.2010-0537

Bauman, D., \& Currie, E. (1980). Partitioning of nutrients during pregnancy and lactation. Journal of Dairy Science, 63, 1514-1529. https://doi.org/10.3168/jds.s0022-0302(80)83111-0

Baumgard, L., Collier, R., \& Bauman, D. (2017). A 100-Year Review: Regulation of nutrient partitioning to support lactation. Journal of Dairy Science, 100, 10352-10366. https://doi.org/10.3168/jds.2017-13242

Beam, S., \& Butler, R. (1999). Effect of energy balance on follicular development and first ovulation in postpartum dairy cows. Journal of Reproduction and Fertility Supplement, 54, 411-424.

Beever, D. (2006). The impact of controlled nutrition during dry period on dairy cow health, fertility and performance. Animal Reproduction Science, 96, 212-226. https://doi.org/10.1016/j.anireprosci.2006.08.002

Beilharz, R., \& Nitter, G. (1998). The missing E: the role of the environment in evolution and animal breeding. Journal of Animal Breeding and Genetics, 115, 439-453. https://doi.org/10.1111/j.1439-0388.1998. tb00366.x

Beilharz, R., Luxford, B., \& Wilkinson, J. (1993). Quantitative genetics and evolution: Is our understanding of genetics sufficient to explain evolution? Journal of Animal Breeding and Genetics, 110, 161-170. https://doi.org/10.1111/j.1439-0388.1993.tb00728.x 
Berge, A., \& Vertenten, G. (2014). A field study to determine the prevalence, dairy herd management systems, and fresh cow clinical conditions associated with ketosis in western European dairy herds. Journal of Dairy Science, 97, 2145-2154. https://doi.org/10.3168/jds.2013-7163

Berry, D., Bermingham, M., Good, M., \& More, S. (2011). Genetic of animal health and disease in cattle. Irish Veterinary Journal, 64, 1-10. https://doi.org/10.1186/2046-0481-64-5

Berry, D., Buckley, F., Dillon, P., Evans, R., Rath, M., \& Veerkamp, R. (2003). Genetic relationship among body condition score, body weight, milk yield, and fertility in dairy cows. Journal Dairy Science, 86, 2193-2204. https://doi.org/10.3168/jds.S0022-0302(03)73809-0

Berry, D., Friggens, N., Lucy, M., \& Roche, J. (2016). Milk production and fertility in cattle. Annual Review Animal Biosciences, 4, 269-290. https://doi.org/10.1146/annurev-animal-021815-111406

Bertics, S., Grummer, R., Cadorniga-Valino, C., \& Stoddard, E. (1992). Effect of prepartum dry matter intake on liver triglyceride concentration and early lactation. Journal of Dairy Science, 75, 1914-1922. https://doi.org/ 10.3168/jds.S0022-0302(92)77951-X

Bobe, G., Young, J., \& Beitz, D. (2004). Invited review: Pathology, aetiology, prevention, and treatment of fat liver in dairy cows. Journal of Dairy Science, 87, 3105-3124. https://doi.org/10.3168/jds.S0022-0302 (04)73446-3

Bollwein, H., Kawashima, C., Shimizu, T., Miyamoto, A., \& Kaske, M. (2014). Impact of metabolism and productive diseases on reproductive function in dairy cows. Reproduction in Domestic Ruminants VII (pp. 4445-462). Nottingham University Press, UK.

Brade, W. (2018). Integration von Merkmalen der Gesundheit in Zuchtprogramme bei Milchrindern unter den Bedingungen der genomisch gestützten Selektion. Tierärztliche Umschau, 71, 73, 3-13.

Bradford, B., Mamedova, L., Minton, J., Drouillard, J., \& Johnson, B. (2009). Daily injection of tumor necrosis factor- $\alpha$ increases hepatic triglycerides and alters transcript abundances of metabolic genes in lactation dairy cattle. Journal of Nutrition, 139, 1451-1456. https://doi.org/10.3945/jn.109.108233

Britt, J. (1992). Impacts of early postpartum metabolism on follicular development and fertility. In E. I. Williams (Ed.), Proceedings of the 24th annual convention/American Association of Bovine Practitioners (pp. 39-43). Orlando, Florida.

Brockman, R. (1979). Roles of insulin and glucagon in the development of ruminant ketosis-a review. The Canadian Veterinary Journal, 20, 121-126.

BRS (Bundesverband Rind und Schwein). (2019). Rinder-und Schweineproduktion in Deutschland 2018. Retrieved from http://www.rindschwein.de

Bucholtz, D., Vidwans, N., Herbosa, C., Schillo, K., \& Foster, D. (1996). Metabolic interfaces between growth hormone and reproduction. V. Pulsatile luteinizing hormone secretion is dependent on glucose availability. Endocrinology, 137, 601-607. https://doi.org/10.1210/endo.137.2.8593808

Butler, R. (2000). Nutritional interactions with reproductive performance in dairy cattle. Animal Reproduction Science, 60-61, 449-457. https://doi.org/10.1016/S0378-4320(00)00076-2

Butler, R. (2003). Energy balance relationships with follicular development, ovulation and fertility in postpartum dairy cows. Livestock Production Science, 83, 211-218. https://doi.org/10.1016/S0301-6226(03)00112-X

Butler, R. (2005). Relationship between negative energy balance with fertility. Advances in Dairy Technology, 17, $35-46$.

Butler, S., Marr, A., Pelton, S., Radcliff, S., Lucy, M., \& Butler, R. (2003). Insulin restores GH responsiveness during lactation-induced negative energy balance in dairy cattle: effects on expression of IGF-I and GH receptor 1A. Journal of Endocrinology, 176, 205-217. https://doi.org/10.1677/joe.0.1760205

Buttchereit, N., Stamer, E., Junge, W., \& Thaller, G. (2012). Genetic parameters for energy balance, fat/protein ratio, body condition score and disease traits in German Holstein cows. Animal Breeding and Genetics, 129, 280-288. https://doi.org/10.1111/j.1439-0388.2011.00976.x

Byrne, A., Southgate, J., Brison, D., \& Leese, H. (2002). Effects of insulin-like growth factors I and II on tumor-necrosis-factor-alpha-induced apoptosis in early murine embryos. Reproduction, Fertility and Development, 14, 79-83. https://doi.org/10.1071/RD01015 
Cai, Z., Guldbrandtsen, B., Lund, M., \& Sahana, G. (2019). Prioritizing candidate genes for fertility in dairy cows using gene-based analysis, functional annotation and differential gene expression. BMC Genomics, 20, 255. https://doi.org/10.1186/s12864-019-5638-9

Canfield, R., \& Butler, R. (1990). Energy balance and pulsatile LH secretion in early postpartum dairy cattle. Domestic Animal Endocrinology, 7, 323-330. https://doi.org/10.1016/0739-7240(90)90038-2

Canfield, R., \& Butler, R. (1991). Energy balance, first ovulation and the effects of naloxone on LH secretion in early postpartum dairy cows. Journal of Animal Science, 69, 740-746. https://doi.org/10.2527/1991. 692740x

Cardoso, F., LeBlanc, S., Murphy, M., \& Drackley, J. (2013). Prepartum nutritional strategy affects reproductive performance in dairy cows. Journal of Dairy Science, 96, 5859-5871. https://doi.org/10.3168/jds.2013-6759

Carvalho, M., Penagaricano, F., Santos, J., DeVries, T., McBride, B., \& Ribeiro, E. (2019). Long-term effects of postpartum clinical diseases on mik production, reproduction, and culling of dairy cows. Journal of Dairy Science, 102, 11701-11717. https://doi.org/10.3168/jds.2019-17025

Chagas, L., Bas, J., Blache, D., Burke, C., Kay, J., Lindsay, D., \& Webb, R. (2007). Invited review: New perspectives on the roles of nutrition and metabolic priorities in the subfertility of high-producing dairy cows. Journal of Dairy Science, 90, 4022-32. https://doi.org/10.3168/jds.2006-852

Cheng, Z., Oguejiofor, C., Swangchan-Uthai, T., Carr, S., \& Wathes, D. (2015). Relationship between circulating urea concentrations and endometrial function in postpartum dairy cows. Animals, 5, 748-773. https://doi.org/10.3390/ani5030382

Clarke, I. (2014). Interface between metabolic balance and reproduction in ruminants: Focus on hypothalamus and pituitary. Hormones and Behavior, 66, 15-40. https://doi.org/10.1016/j.yhbeh.2014.02.005

Coffey, M., Simm, G., Oldham, J., Hill, W., \& Brotherstone, S. (2004). Genotype and diet effect on energy balance in the first three lactations of dairy cows. Journal of Dairy Science, 87, 4318-4326. https://doi.org/ 10.3168/jds.S0022-0302(04)73577-8

Compton, C., Heuer, C., Thomsen, P., Carpenter, T., Phyn, C., \& McDougall, S. (2017). Invited review: A systematic literature review and meta-analysis of mortality and culling in dairy cattle. Journal of Dairy Science, 100, 1-16. https://doi.org/10.3168/jds.2016-11302

Danfær, V. (1994). Nutrient metabolism and utilization in the liver. Livestock Production Science, 39, $115-127$. https://doi.org/10.1016/0301-6226(94)90163-5

Dann, H., Litherland, N., Underwood, J., Bionaz, M., D’Angelo, A., McFadden, J., \& Drackley, J. (2006). Diets during far-off and close-up dry periods affect periparturient metabolism and lactation in multiparous cows. Journal of Dairy Science, 89, 3563-3577. https://doi.org/10.3168/jds.S0022-0302(06)72396-7

Day, M., Imakawa, D., Zalesky, D., Kittok, R., \& Kinder, J. (1986). Effects of restrictions of dietary energy intake during the prepubertal period on secretion of luteinizing hormone and responsiveness of the pituitary to luteinizing hormone-releasing hormone in heifers. Journal of Animal Science, 62, 1641-1648. https://doi.org/10.2527/jas1986.6261641x

Dechow, C., Rogers, G., \& Clay, J. (2002). Heritability and correlations among body condition score loss, body condition score, production and reproductive performance. Journal of Dairy Science, 85, 3062-3070. https://doi.org/10.3168/jds.S0022-0302(02)74393-2

Demigné, C., Yacoub, C., Rémésy, C., \& Fafournoux, P. (1986). Propionate and butyrate metabolism in rat or sheep hepatocytes. Biochimica Biophysica Acta, 875, 535-842. https://doi.org/10.1016/0005-2760(86) 90074-3

Diskin, M., \& Morris, D. (2008). Embryonic and early foetal loss in cattle and other ruminants. Reproduction Domestic Animals, 43(Suppl. 2), 260-257. https://doi.org/10.1111/j.1439-0531.2008.01171.x

Diskin, M., Mackey, D., Roche, J., \& Sreenan, J. (2003). Effects of nutrition and metabolic status on circulating hormones and ovarian follicle development in cattle. Animal Reproduction Science, 78, 345-370. https://doi.org/10.1016/S0378-4320(03)00099-X

Dobson, H., Walker, S., Morris, M., Routly, J., \& Smith, R. (2008). Why is getting more difficult to successfully inseminate dairy cows? Animal, 2, 1104-1111. https://doi.org/10.1017/S175173110800236X 
Dohoo, I., Martin, S., McMillan, I., \& Kennedy, B. (1984). Disease, production and culling in Holstein-Friesian cows. II. Age, season and sire effects. Preventive Veterinary Medicine, 2, 655-670. https://oi.org/10.1016/ 0167-5877(84)90012-6

Drackley, J., \& Cardoso, F. (2014). Prepartum and postpartum nutritional management to optimize fertility in high-yielding dairy cows in confined TMR systems. Animal, 8(Suppl.), 5-14. https://doi.org/10.1017/ S1751731114000731

Drackley, J., Overton, T., \& Douglas, G. (2001). Adaptations of glucose and long-chain fat acid metabolism in the liver of dairy cows during periparturient period. Journal of Dairy Science, 84, E100-E112. https://doi.org/10.3168/jds.S0022-0302(01)70204-4

Du, X., Zhu, Y., Peng, Z., Cui, Y., Zhang, Q., Shi, Z., ... Liu, G. (2018). High concentrations of fat acids and $\beta$-hydroxybutyrate impair the growth hormone-mediated hepatic JAK2-STAT5 pathway in clinically ketotic cows. Journal of Dairy Science, 101, 3476-3487. https://doi.org/10.3168/jds.2017-13234

Duffield, T., Lissemore, K., McBride, B., \& Leslie, K. (2009). Impact of hyperketonemia in early dairy cows on health and production. Journal of Dairy Science, 92, 571-580. https://doi.org/10.3168/jds.2008-1507

Dupont, J., Scaramuzzi, R., \& Reverchon, M. (2014). The effect of nutrition and metabolic status on the development of follicles, oocytes and embryos in ruminants. Animal, 8, 1031-1044. https://doi.org/10.1017/ S1751731114000937

Emanuelson, U. (1988). Recording of production diseases in cattle and possibilities for genetic improvement. Livestock Production Science, 20, 89-106. https://doi.org/10.1016/0301-6226(88)90055-3

Emery, R., Liesmann, J., \& Herdt, T. (1992). Metabolism of long chain fat acids by ruminant liver. Journal of Nutrition, 122, 832-837. https://doi.org/10.1093/jn/122.suppl_3.832

Esposito, G., Irons, P., Webb, C., \& Chapwanya, A. (2014). Interactions between negative energy balance, metabolic diseases, uterine health and immune response in transition dairy cows. Animal Reproduction Science, 30, 60-71. https://doi.org/10.1016/j.anireprosci.2013.11.007

Estienne, M., Schillo, K., Green, M., \& Boling, J. (1989). Free fatty acids suppress growth hormone, but not luteinizing hormone secretion in sheep. Endocrinology, 125, 85-91. https://doi.org/10.1210/endo-125-1-85

Fan, Y., Menon, R., Cohen, P., Hwang, D., Clemens, T., DiGirolamo, D., \& Sperling, M. (2009). Liver-specific deletion of the growth hormone receptor reveals essential role of growth hormone signaling in hepatic lipid metabolism. Journal of Biological Chemistry, 284, 19937-1944. https://doi.org/10.1074/jbc.M109.014308

Fleischer, P., Metzner, M., Beyerbach, M., Hoedemaker, M., \& Klee, W. (2001). The relationship between milk yield and the incidence of some diseases in dairy cows. Journal of Dairy Science, 84, 2025-2035. https://doi.org/10.3168/jds.S0022-0302(01)74646-2

Fraser, A., \& Broom, D. (1990). Farm Animal and Welfare. Wallingford: CABI.

Friggens, N. (2003). Body lipid reserves and the reproductive cycle: towards a better understanding. Livestock Production Science, 83, 219-236. https://doi.org/10.1016/S0301-6226(03)00111-8

Friggens, N., \& Newbold, J. (2007). Towards a biological basis for prediction nutrient partitioning: The dairy cow as an example. Animal, 1, 87-97. https://doi.org/10.1017/S1751731107657772

Friggens, N., Disenhaus, C., \& Petit, H. (2010). Nutritional sub-fertility in the dairy cow: Towards improved reproductive management through a better biological understanding. Animal, 4, 1197-1213. https://doi.org/ $10.1017 / \mathrm{S} 1751731109991601$

Frigo, E., Dechow, C., Pedron, O., \& Cassell, B. (2010). The genetic relationship of body weight and early lactation health disorders in two experimental herds. Journal of Dairy Science, 93, 1184-1192. https://doi.org/10.3168/jds.2009-2313

Garverick, H., Harris, M., Vogel-Bluel, R., Sampson, J., Bader, J., Lamberson, W., ... Youngquist, R. (2013). Concentrations of nonesterified acids and glucose in blood of periparturient dairy cows are indicative of pregnancy success at first insemination. Journal of Dairy Science, 96, 181-188. https://doi.org/10.3168/ jds.2012-5619

Geelen, M., \& Wensing, T. (2006). Studies on hepatic lipidosis and coinciding health and fertility problems of high-producing dairy cows using the "Utrecht fatty liver model of dairy cows". A review. Veterinary Quarterly, 28, 90-104. https://doi.org/10.1080/01652176.2006.9695214 
Gernand, E., Rehbein, P., von Borstel, U., \& König, S. (2012). Incidences of and genetic parameters for mastitis, claw disorders, and common health traits recorded in dairy cattle contract herds. Journal of Dairy Science, 95, 2144-2156. https://doi.org/10.3168/jds.2011-4812

Giesecke, D. (1986). Insulin deficiency and metabolic disorders in high-yielding dairy cows. Journal of South African Veterinary Association, 57, 67-70.

Gobikrushanth, M., Purfield, D., Colazo, M., Wand, Z., Butler, S., \& Ambrose, D. (2018). The relationship between serum insulin-like growth factor-1 (IGF-1) concentration and reproductive performance, and genome wide associations for serum IGF-1 in Holstein cows. Journal of Dairy Science, 101, 9154-9167. https://doi.org/10.3168/jds.2018-14535

Goldhawk, C., Chapinal, N., Veira, D. M., Weary, D., \& von Keyserlingk, M. (2009). Prepartum feeding behavior is an early indicator of subclinical ketosis. Journal of Dairy Science, 92, 4971-7. https://doi.org/ $10.3168 /$ jds.2009-2242

Gong, Z., Tas, E., Yakar, S., \& Muzumdar, R. (2017). Hepatic lipid metabolism and non-alcoholic fatty liver disease in aging. Molecular and Cellular Endocrinology, 455, 115-130. https://doi.org/10.1016/j.mce. 2016.12.022

Green, J., Meyer, J., Williams, A., Newsom, E., Keisler, D., \& Lucy, M. (2012). Pregnancy development from da0y 28 t0 42 of gestation in postpartum Holstein cows that were either milked (lactating) or not milked (not lactating) after calving. Reproduction, 143, 699-711. https://doi.org/10.1530/REP-11-0461

Grinberg, N., Elazar, S., Rosenshine, I., \& Shpigel, N. (2008). Beta-hydroxybutyrate abrogates formation of bovine neutrophil extracellular traps and bactericidal activity against mammary pathogenic Escherichia coli. Infection and Immunity, 76, 2802-2807. https://doi.org/10.1128/IAI.00051-08

Gröhn, Y., Lindberg, L., Bruss, M., \& Farver, T. (1983). Fat infiltration of liver in spontaneously ketotic cows. Journal of Dairy Science, 66, 2320-2328. https://doi.org/10.3168/jds.S0022-0302(83)82088-8

Gross, J., \& Bruckmaier, R. (2015). Repeatability of metabolic responses to a nutrient deficiency in early and mid lactation and implications for robustness of dairy cows. Journal of Dairy Science, 98, 8634-8643. https://doi.org/10.3168/jds.2014-9246

Grummer, R. (1993). Etiology of lipid-related metabolic disorders in periparturient dairy cows. Journal of Dairy Science, 76, 3882-3896. https://doi.org/10.3168/jds.S0022-0302(93)77729-2

Hammon, H., Stürmer, G., Schneider, F., Tuchscherer, A., Blum, H., Engelhard, T., \& Kanitz, W. (2009). Performance and metabolic and endocrine changes with emphasis on glucose metabolism in high-yielding dairy cows with high and low fat content in liver after calving. Journal of Dairy Science, 92, 1554-1556. https://doi.org/10.3168/jds.2008-1634

Harrison, R., Ford, S., Young, J., Conley, A., \& Freeman, A. (1990). Increased milk production versus reproductive and energy status of high producing cows. Journal of Dairy Science, 73, 2749-2758. https://doi.org/10.3168/jds.S0022-0302(90)78960-6

Hart, I., Bines, J., Balch, C., \& Cowie, A. (1975). Hormone and metabolic differences between lactating beef and dairy cattle. Life Sciences, 16, 1285-1292. https://doi.org/10.1016/0024-3205(75)90313-6

Hayirli, A. (2006). The role of exogenous insulin in the complex of hepatic lipidosis and ketosis associated with insulin resistance phenomenon in postpartum dairy cattle. Veterinary Research Communication, 30, 749-774. https://doi.org/10.1007/s11259-006-3320-6

Hayirli, A., Bertics, S., \& Grummer, R. (2002). Effects of slow-release insulin on production, liver triglyceride, and metabolic profiles of Holsteins in early lactation. Journal of Dairy Science, 85, 2180-2191. https://doi.org/10.3168/jds.S0022-0302(02)74297-5

Hazel, A., Heins, B., \& Hansen, L. (2017). Fertility, survival, and conformation of Montebéliarde x Holstein and Viking Red x Holstein crossbred cows compared with pure Holstein cows during first lactation in 8 commercial dairy herds. Journal of Dairy Science, 100, 4139-4149. https://doi.org/10.3168/jds.2017-12824

Herdt, T. (2000). Ruminant adaptation to negative energy balance. Influences on the etiology of ketosis and fat liver. Veterinary Clinics of North America: Food Animal Practice, 16, 215-230. https://doi.org/10.1016/ S0749-0720(15)30102-X 
Heringstad, B., \& Østerås, O. (2013). More than 30 years of health recording in Norway. Health Data Conference, ICAR 2013, Århus, Denmark. Retrieved July 15, 2016, from http://www.icar.org./wp-content/ uploads/2015/09/Heringstadbd1.pdf

Heringstad, B., Egger-Danner, C., Charfeddine, N., Pryce, J., Stock, K. F., Kofler, J., \& Cole, J. B. (2018). Invited review: Genetics and claw health: Opportunities to enhance claw health by genetic selection. Journal of Dairy Science, 101, 4801-4821. https://doi.org/10.3168/jds.2017-13531

Heringstad, B., Klemetsdal, G., \& Ruane, J. (2000). Selection for mastitis resistance in dairy cattle: A review with focus on the situation in the Nordic countries. Livestock Production Science, 64, 95-106. https://doi.org/10.1016/S0301-6226(99)00128-1

Heringstad, B., Klemetsdal, G., \& Steiner, T. (2007). Selection responses for disease resistance in two selection experiments with Norwegian Red Cows. Journal of Dairy Science, 90, 2419-2426. https://oi.org/10.3168/ jds.2006-8056

Hill, J., \& Elias, C. (2018). Neuroanatomical framework of the metabolic control of reproduction. Physiological Reviews, 98, 2349-2380. https://doi.org/10.1152/physrev.00033.2017

Hove, K. (1974). Nocturnal plasma insulin levels in cows with varying levels of plasma ketone bodies: Relations to plasma sugar and acetoacetate. Acta Endocrinologica, 76, 513-524. https://doi.org/10.1530/acta.0. 0760513

Huber, K. (2017). Invited review: resource allocation mismatch as pathway to disproportionate growth in farm animal-prerequisite for disturbed health. Animal, 14, 1-9. https://doi.org/10.1017/S1751731117002051

Hurley, A., Lopez-Villabos, N., McParland, S., Lewis, E., Kennedy, E., O’Donovan, M., \& Berry, D. (2018). Characteristics of feed efficiency within and across lactation in dairy cows and the effect of genetic selection. Journal of Dairy Science, 101, 1267-1280. https://doi.org/10.3168/jds.2017-12841

I'Anson, H., Manning, J., Herbosa, C., Pelt, C., Friedman, C., Wood, R., \& Foster, D. (2000). Central inhibition of gonadotropin-releasing hormone secretion in growth-restricted hypogonadotropic female sheep. Endocrinology, 141, 520-527. https://doi.org/10.1210/endo.141.2.7308

Ideraabdullah, F., \& Zeisel, S. (2018). Dietary modulation of the epigenome. Physiological Reviews, 98, 67-695. https://doi.org/10.1152/physrev.00010.2017

Ingvartsen, K. (2006). Feeding-and management-related diseases in transition cow. Physiological adaptations around calving and strategies to reduce feeding-related diseases. Animal Feed Science and Technology, 126, 175-213. https://doi.org/10.1016/j.anifeedsci.2005.08.003

Israeli Dairy Board. (2017). The profitability of the Israeli dairy cattle branch in 2016. Israeli Dairy Board, Yahud, Israel. Retrieved from https://www.israeldairy.com/category/israel-dairy-board

Jorritsma, R., César, M., Hermans, J., Kruitwagen, C., Vos, P., \& Kruip, T. (2004). Effects of non-esterified fatty acids on bovine granulosa cells and developmental potential of oocytes in vitro. Animal Reproduction Science, 81, 225-235. https://doi.org/10.1016/j.anireprosci.2003.10.005

Karacaören, B., Jaffrézic, F., \& Kadarmideen, H. (2006). Genetic parameters for functional traits in dairy cattle from random regression models. Journal of Dairy Science, 89, 791-798. https://doi.org/10.3168/jds.S0022-0302(06)72141-5

Katoh, N. (2002). Relevance of apolipoproteins in the development of fat liver and fat liver-related peripartum diseases in dairy cows. The Journal of Veterinary Medical Science, 64, 293-307. https://doi.org/10.1292/ jvms.64.293

Kaufman, E., Asselstine, V., LeBlanc, S., Duffield, T., \& DeVries, T. (2018). Association of rumination time and health status with milk yield and composition in early-lactation dairy cows. Journal of Dairy Science, 101, 462-471. https://doi.org/10.3168/jds.2017-12909

Kawashima, C., Matsui, M., Shimizu, T., Kida, K., \& Miyamoto, A. (2012). Nutritional factors that regulates ovulation of the dominant follicle during the first follicular wave postpartum in high-producing dairy cows. Journal of Reproduction and Development, 58, 10-16. https://doi.org/10.1262/jrd.11-139N

Kerestes, M., Faigl, V., Kulcsar, M., Balogh, O., Foldi, J., Febel, H., \& Huszenicza, G. (2009). Periparturient insulin secretion and whole-body insulin responsiveness in dairy cows showing various forms of ketone pattern with and without puerperal metritis. Domestic Animal Endocrinology, 37, 250-261. https://doi.org/ 10.1016/j.domaniend.2009.07.003 
Knaus, W. (2009). Dairy cows trapped between performance demands and adaptability. Journal of the Science of Food and Agriculture, 89, 1107-1114. https://doi.org/10.1002/jsfa.3575

Knight, C., Beever, D., \& Sorensen, A. (1999). Metabolic loads to be expected from different genotypes under different systems. In J. Oldham, G. Simm, A. Groen, B. Nielsen, J. Pryce, \& T. Lawrence (Eds.), Metabolic stress in dariy cows (Occasional Publication No. 24, pp. 27-35). Pencuit, Midlothian: British Society of Animal Science. https://doi.org/10.1017/S1463981500043053

Koeck, A., Jamrozik, J., Schenkel, F., Moore, R., Lefebvre, D., Kelton, D., \& Miglior, F. (2014a). Genetic analysis of milk $\beta$-hydroxybutyrate and its association with fat-to-protein ratio, body condition score, clinical ketosis, and displaced abomasum in early first lactation of Canadian Holsteins. Journal of Dairy Science, 97, 7286-7292. https://doi.org/10.3168/jds.2014-8405

Koeck, A., Loker, S., Miglior, F., Kelton, D., Jamrozik, J., \& Schenkel, F. (2014b). Genetic relationship of clinical mastitis, cystic ovaries, and lameness with milk yield and somatic cell score in first-lactation Canadians Holsteins. Journal of Dairy Science, 97, 5806-5813. https://doi.org/10.3168/jds.2013-7785

Krattenmacher, N., Thaller, G., \& Tetens, J. (2019). Analysis of the genetic architecture of energy balance and its major determinants dry matter intake and energy-corrected milk yield in primiparous Holstein cows. Journal of Dairy Science, 102, 3241-3253. https://doi.org/10.3168/jds.2018-15480

Kroezen, V., Schenkel, F., Miglior, F., Baes, C., \& Squires, E. (2018). Candidate gene association analyses for ketosis resistance in Holsteins. Journal of Dairy Science, 101, 5240-5249. https://doi.org/10.3168/ jds.2017-13374

Kronfeld, D. (1965). Growth hormone-induced ketosis in the cow. Journal of Dairy Science, 48, 342-346. https://doi.org/10.3168/jds.s0022-0302(65)88225-x

Kushibiki, S., Hodate, K., Ueda, Y., Shingu, H., Mori, Y., Itoh, T., \& Yokomizo, Y. (2000). Administration of recombinant bovine tumor necrosis factor-alpha affects intermediary metabolism and insulin and growth hormone secretion in dairy heifers. Journal of Animal Science, 78, 2164-2171. https://doi.org/10.2527/ $2000.7882164 x$

Lacasse, P., Vanacker, N., Ollier, S., \& Ster, C. (2018). Innovative dairy cow management to improve resistance to metabolic and infectious diseases during the transition period. Research in Veterinary Science, 116, 40-46. https://doi.org/10.1016/j.rvsc.2017.06.020

Lean, I., Celi, P., Raadsma, H., McNamara, J., \& Rabiee, A. (2012). Effect of dietary crude protein on fertility: Meta-analysis and meta-regression. Animal Feed Science and Technology, 171, 31-42. https://doi.org/ 10.1016/j.anifeedsci.2011.09.017

Lean, I., Farver, T., Troutt, H., Bruss, M., Galland, J., Baldwin, R., \& Weaver, L. (1992). Time series cross-correlation analysis of postparturient relationships among serum metabolites and yield variables in Holstein cows. Journal of Dairy Science, 75, 1891-900. https://doi.org/10.3168/jds.S0022-0302(92)77949-1

Lehner, S., Zerbin, I., Doll, K., Rehage, J., \& Distl, O. (2018). A genome-wide association study for left-sided displacement of the abomasum using a high-density single nucleotide polymorphism array. Journal of Dairy Science, 101, 1258-1266. https://doi.org/10.3168/jds.2017-13216

Leroy, J., Vanholder, T., Mateusen, B., Christophe, A., Opsomer, G., de Kruif, A., \& Van Soom, A. (2005). Non-esterified fat acids in follicular fluid of dairy cows and their effect on development capacity of bovine oocytes in vitro. Reproduction, 130, 485-495. https://doi.org/10.1530

Leroy, J., Vanholder, T., Opsomer, G., Van Soom, A., \& de Kruif, A. (2006). The in vitro development of bovine oocytes after maturation in glucose and $\beta$-hydroxybutyrate concentrations with negative energy balance in dairy cows. Reproduction in Domestic Animals, 41, 119-123. https://doi.org/10.1111/j.1439-0531.2006. 00650.x

Leroy, J., Vanholder, T., van Knegsel, A., Garcia-Ispierto, I., \& Bols, P. (2008). Nutrient prioritization in dairy cows early postpartum: Mismatch between metabolism and fertility. Reproduction in Domestic Animals, 43, (Suppl. 2), 96-103. https://doi.org/10.1111/j.1439-0531.2008.01148.x

Levin, B. (2006). Metabolic sensing neurons and the control of the energy homeostasis. Physiology and Behavior, 89, 486-489. https://doi.org/10.1016/j.physbeh.2006.07.003 
Li, C., Dai, S., Lu, J., Zhao, B., Wang, J., Mu, Y., \& Dong, Q. (2018a). Methylglyoxal: A newly detected and potentially harmful metabolite in the blood of ketotic dairy cows. Journal of Dairy Science, 101, 8513-8523. https://doi.org/10.3168/jds.2018-14448

Li, P., Li, X., Fu, S., Wu, C., Wang, X., Yu, G., \& Liu, G. (2012). Alterations of fatty acid $\beta$-oxidation capability in the liver of ketotic cows. Journal of Dairy Science, 95, 1759-1766. https://doi.org/10.3168/jds.2011-458

Li, X., Egervari, G., Wang, Y., Berger, S., \& Lu, Z. (2018b). Regulation of chromatin and gene expression by metabolic enzymes and metabolites. Nature Reviews Molecular Cell Biology, 19, 563-578. https://doi.org/ $10.1038 / \mathrm{s} 41580-018-0029-7$

Liinamo, A., Mäntysaari, P., \& Mäntysaari, E. (2012). Short communication: Genetic parameters for feed intake, production, and extent of negative energy balance in Nordic Red dairy cattle. Journal of Dairy Science, 95, 6788-6794. https://doi.org/10.3168/jds.2012-5342

Liu, Z., Cordoba-Chacon, J., Kineman, R., Cronstein, B., Muzumdar, R., Gong, Z., \& Yakar, S. (2016). Growth Hormone Control of Hepatic Lipid Metabolism. Diabetes, 65, 3598-3609. https://doi.org/10.2337/ db16-0649

Loor, J., Dann, H., Everts, R., Oliveira, R., Green, C., Guretzky, N., \& Drackley, J. (2005). Temporal gene expression profiling of liver from periparturient dairy cows reveals complex adaptive mechanisms in hepatic function. Physiological Genomics, 23, 217-26. https://doi.org/10.1152/physiolgenomics.00132.2005

Loor, J., Everts, R., Bionaz, M., Dann, H., Morin, D., Oliveira, R., \& Lewin, H. (2007). Nutrition-induced ketosis alters metabolic and signaling gene networks in liver of periparturient dairy cows. Physiological Genomics, 32, 105-16. https://doi.org/10.1152/physiolgenomics.00188.2007

Lucy, M. (2001). ADSA Foundation Scholar Award. Reproductive loss in high-producing dairy cattle: Where will it end? Journal of Dairy Science, 84, 1277-1293. https://doi.org/10.3168/jds.S0022-0302(01)70158-0

Lucy, M. (2003). Mechanisms linking nutrition and reproduction in postpartum cows. Reproduction, 61(Suppl.), 415-427.

Lucy, M. (2004). Mechanisms linking the somatotropic axis with insulin: Lessons from the postpartum dairy cow. New Zealand Society of Animal Production, 64, 19-23.

Lucy, M. (2008). Functional differences in growth hormone and insulin-like growth factor axis in cattle and pigs: Implications for post-partum nutrition and reproduction. Reproduction of Domestic Animals, 43(Suppl.), 31-39. https://doi.org/10.1111/j.1439-0531.2008.01140.x

Lucy, M. (2012). Growth hormone regulation of follicular growth. Reproduction Fertility and Development, 24, 19-28. https://doi.org/10.1071/RD11903

Lucy, M. (2016). Mechanisms linking prepartum metabolism with reproduction. WCDS Advances in Dairy Technology, 28, 250-269.

Lucy, M., Butler, S., \& Garverick, H. (2014). Endocrine and metabolic mechanisms linking postpartum glucose with early embryonic and foetal development in dairy cows. Animal, 8, 82-90. https://oi.org/10.1017/ S1751731114000482

Lucy, M., Jiang, H., \& Kobayashi, Y. (2001). Changes in the somatotropic axis associated with the initiation of lactation. Journal of Dairy Science, 84, E113-E119. https://doi.org/10.3168/jds.S0022-0302(01)70205-6

Lyons, D., Freeman, A., \& Kuck, A. (1991). Genetics of health traits in Holstein cattle. Journal of Dairy Science, 74, 1092-1100. https://doi.org/10.3168/jds.S0022-0302(91)78260-X

Mansouryar, M., Mirzaei-Alamouti, H., Dehghan Banadaky, M., Sauerwein, H., Mielenz, M., \& Nielsen, M. (2018). Short communication: Relationship between body condition score and plasma adipokines in early-lactating Holstein dairy cows. Journal of Dairy Science, 101, 8552-8558. https://doi.org/10.3168/ jds.2017-14122

Manzanilla-Pech, M., Veerkamp, R., Calus, M., Zom, R., van Knegsel, A., Pryce, A., \& De Haas, Y. (2014). Genetic parameters across lactation for feed intake, fat-and protein corrected milk, and live weight in first-parity Holstein cattle. Journal of Dairy Science, 97, 5851-5862. https://doi.org/10.3168/jds.2014-8165

Martens, H. (2016). Leistung und Gesundheit von Milchkühen: Bedeutung von Genetik (Ursache) und Management (Wirkung). Ein Beitrag zur Diskussion. Tierärztliche Praxis (G), 44, 253-258. https://doi.org/ 10.15653/TPG-160312 
Martin, R., Barkema, H., Brito, L., Narayana, S., \& Miglior, F. (2018). Symposium review: Novel strategies to genetically improve mastitis resistance in dairy cattle. Journal of Dairy Science, 101, 2724-2736. https://doi.org/10.3168/jds.2017-13554

McArt, J., Nydam, D., Oetzel, G., Overton, T., \& Ospina, P. (2013). Elevated non-esterified fat acids and $\beta$-hydroxybutyrate and their association with transition dairy cows performance. Veterinary Journal, 198, 560-570. https://doi.org/10.1016/j.tvj1.2013.08.011

McCarthy, S., Waters, S., Kenny, D., Diskin, M., Fitzpatrick, R., Patton, J., \& Morris, D. (2010). Negative energy balance and hepatic gene expression patterns in high-yielding dairy cows during the early postpartum period: A global approach. Physiological Genomics, 42A, 188-199. https://doi.org/10.1152/ physiolgenomics.00118.2010

McClure, T. (1968). Hypoglycaemia, an apparent cause of unfertility of lactating cows. British Veterinary Journal, 124,126-130. https://doi.org/10.1016/s0007-1935(17)39506-4

McFadden, J., \& Rico, J. (2019). Invited review: Sphingolipoid biology in the dairy cow: The emerging role of ceramide. Journal of Dairy Science, 102, 7619-7639. https://doi.org/10.3168/jds.2018-16095

McMamara, J., \& Hilllers, J. (1986). Regulation of bovine adipose tissue metabolism during lactation. 2. Lipolysis response to milk production and energy intake. Journal of Dairy Science, 69, 3042-3050. https://doi.org/ 10.3168/jds.S0022-0302(86)80767-6

Miglior, F., Fleming, A., Malchiodi, F., Brito, L., Martin, P., \& Baes, C. (2017). A 100-Year Review: Identification and genetic selection of economically important traits in dairy cattle. Journal of Dairy Science, 100, 10251-10271. https://doi.org/10.3168/jds.2017-12968

Miglior, F., Muir, B., \& Van Doormaal, B. (2005). Selection indices in Holstein cattle of various countries. Journal of Dairy Science, 88, 1255-1263. https://doi.org/10.3168/jds.S0022-0302(05)72792-2

Montgomery, M., De Nardo, W., \& Watt, M. (2018). Impact of lipotoxicity on tissue "cross talk" and metabolic regulation. Physiology, 34, 134-149. https://doi.org/10.1152/physiol.00037.2018

Moore, S., Fair, T., Lonergan, P., \& Butler, S. (2014b). Genetic merit for fertility traits in Holstein cows: IV. Transition period, uterine health, and resumption of fertility. Journal of Dairy Science, 97, $2740-2752$. https://doi.org/10.3168/jds.2013-7278

Moore, S., Scully, S., Browne, J., Fair, T., \& Butler, S. (2014a). Genetic merit for fertility traits in Holstein cows: V. Factors affecting circulating progesterone concentrations. Journal of Dairy Science, 97, 5543-57. https://doi.org/10.3168/jds.2014-8133

Murahashi, K., Buchholtz, D., Nagatani, S., Tsukahara, S., Tuskamura, M., Foster, D., \& Maeda, K. (1996). Suppression of luteinizing hormone pulses by restriction of glucose availability is mediated by sensors in the brain stem. Endocrinology, 137, 1171-1176. https://doi.org/10.1210/endo.137.4.8625886

Murondoti, A., Jorritsma, R., Beynen, A., Wensing, T., \& Geelen, M. (2004). Activities of the enzymes of hepatic gluconeogenesis in periparturient cows with induced fat liver. Journal of Dairy Research, 71, 129-134. https://doi.org/10.1017/S0022029904000020

Nafikov, R., Ametaj, B., Bobe, G., Koehler, K., \& Beitz, D. (2006). Prevention of fatty liver in transition dairy cows by subcutaneous injections of glucagon. Journal of Dairy Science, 89, 1533-1545. https://doi.org/ 10.3168/jds.S0022-0302(06)72221-4

Nagatani, S., Bucholtz, D., Murahashi, K., Esatico, M., Tuskamura, H., Foster, D., \& Maeda, K. (1996). Reduction of glucose availability suppresses pulsatile luteinizing hormone release in female and male rats. Endocrinology, 137, 1166-1170. https://doi.org/10.1210/endo.137.4.8625885

Narita, T., Weinert, B., \& Choudhary, C. (2019). Functions and mechanisms of non-histone protein acetylation. Nature Reviews Molecular Cell Biology, 20,156-174. https://doi.org/10.1038/s41580-018-0081-3

Ohkura, S., Ohkura, S., Tanaka, T., Nagatani, S., Bucholtz, D., Tsukamura, H., \& Foster, D. (2000). Central, but not peripheral, glucose-sensing mechanisms mediate glucoprivic suppression of pulsatile luteinizing hormone secretion in the sheep. Endocrinology, 141, 4472-4480. https://doi.org/10.1210/endo.141.12.7853

Ohtsuka, H., Koiwa, M., Hatsugaya, A., Kudo, K., Hoshi, F., Itoh, N., \& Kawamura, S. (2001). Relationship between serum TNF activity and insulin resistance in dairy cows affected with naturally occurring fat liver. Journal of Veterinary Medical Science, 63, 1021-1025. https://doi.org/10.1292/jvms.63.1021 
Oikonomou, G., Arsenos, G., Valergakis, G., Tsiaras, A., Zygoyiannis, D., \& Banos, G. (2008a). Genetic relationship of body energy and blood metabolites with reproduction in Holstein cows. Journal of Dairy Science, 91, 4323-4332. https://doi.org/10.3168/jds.2008-1018

Oikonomou, G., Valergakis, G., Arsenos, G., Roubies, N., \& Banos, G. (2008b). Genetic profile of body energy and blood metabolites traits across lactation in primiparous Holstein cows. Journal of Dairy Science, 91, 2814-2822. https://doi.org/10.3168/jds.2007-0965

Oldham, J. (1984). Protein-energy relationship in dairy cow. Journal of Dairy Science, 67, 1090-1114. https://doi.org/10.3168/jds.S0022-0302(84)81410-1

Oliveira, H., Brito, L., Lourenco, D., Silva, F., Jamrozik, J., Schaeffer, L., \& Schenkel, F. (2019). Invited review: Advances and applications of random regression models: From quantitative genetics to genomics. Journal of Dairy Science, 102, 7664-7683. https://doi.org/10.3168/jds.2019-16265

Oltenacu, P., \& Broom, D. (2010). The impact of genetic selection for increased milk yield on the welfare of dairy cows. Animal Welfare, 19, 39-49.

Opsina, P., Nydam, D., Stokol, T., \& Overton, T. (2010). Association of elevated nonesterified fat acids and $\beta$-hydroxybutyrate concentrations with early lactation performance and milk production in transition dairy cattle in the northeastern United States. Journal of Dairy Science, 93, 1596-1603. https://doi.org/10.3168/ jds.2009-2852

Ortega, H., Marelli, B., Rey, F., Amweg, A., Díaz, P., Stangaferro, M., \& Salvetti, N. (2015). Molecular aspects of bovine cystic ovarian disease pathogenesis. Reproduction, 149, R251-64. https://doi.org/10.1530/ REP-14-0618

Ott, R. (1996). Animal selection and breeding techniques that create diseased populations and compromise welfare. Journal of the American Veterinary Medical Association, 208, 1969-1975.

Overton, T., McArt, J., \& Nydam, D. (2017). A 100-year review: Metabolic health indicators and management of dairy cattle. Journal of Dairy Science, 100, 10398-10417. https://doi.org/10.3168/jds.2017-13054

Parker Gaddis, K., Cole, J., Clay, J., \& Maltecca, C. (2014). Genomic selection for producer-recorded health event data in US dairy cattle. Journal of Dairy Science, 97, 3190-3199. https://doi.org/10.3168/ jds.2013-7543

Parker Gaddis, K., Megonigal Jr., J., Clay, J., \& Wolfe, C. (2018). Genome-wide association study in US Jersey using producer-recorded data. Journal of Dairy Science, 101, 413-424. https://doi.org/10.3168/jds. 2017-13383

Porestky, L., Cataldo, N., Rosenwaks, Z., \& Giudice, L. (1999). The insulin related ovarian regulatory system in health and disease. Endocrinological Reviews, 20, 535-582. https://doi.org/10.1210/edrv.20.4.0374

Pritchard, T., Coffey, M., \& Wall, E. (2013). Understanding the genetics of survival in dairy cows. Journal of Dairy Science, 96, 3296-3309. https://doi.org/10.3168/jds.2012-6219

Pryce, I., Veerkamp, R., Thompson, R., Hill, W., \& Simm, G. (1997). Genetic aspects of common health disorders and measures of fertility in Holstein Friesian dairy cattle. Animal Science, 65, 353-360. https://doi.org/10.1017/S1357729800008559

Pryce, J., Parker Gaddis, K., Koeck, A., Bastin, C., Abdelsayed, M., Gengler, N., \& Cole, J. (2016). Invited review: Opportunities for genetic improvement of metabolic diseases. Journal of. Dairy Science, 99, 6855-6873. https://doi.org/10.3168/jds.2016-10854

Pushpakumara, P., Gardner, N., Reynolds, C., Beever, D., \& Wathes, D. (2003). Relationships between transition period diet, metabolic parameters and fertility in lactating dairy cows. Theriogenology, 60, 1165-1185. https://doi.org/10.1016/S0093-691X(03)00119-5

Pushpakumara, P., Robinson, R., Demmers, K., Mann, G., Sinclair, K., Webb, R., \& Wathes, D. (2002). Expression of the insulin-like growth factor (IGF) system in the bovine oviduct at estrus and during early pregnancy. Reproduction, 123, 859-868. https://doi.org/10.1530/rep.0.1230859

Raboisson, D., Mounié, M., \& Maigné, E. (2014). Diseases, reproduction performance, and changes in milk production associated with subclinical ketosis in dairy cows: A meta-analysis and review. Journal of Dairy Science, 97, 7547-7563. https://doi.org/10.3168/jds.2014-8237 
Rauw, M., Kanis, E., Nordhuizen, E., \& Grommers, F. (1998). Undesirable side effects of selection for high production efficiency in farm animals: A review. Livestock Production Science, 56, 15-33. https://doi.org/ 10.1016/S0301-6226(98)00147-X

Reid, I. (1982). Fat liver in dairy cows-incidence, severity, pathology and functional consequences. Bovine Practitioner, 17, 149-150.

Reist, M., Erdin, D., Van Euw, D., Tschümperlin, K., Leuenberger, H., Hammon, H., \& Blum, J. (2003). Postpartum reproduction function: association with energy, metabolic and endocrine status in high yielding cows. Theriogenology, 59, 1707-1723. https://doi.org/10.1016/S0093-691X(02)01238-4

Reynolds, C., Aikman, P., Lupoli, B., Humphries, D., \& Beever, D. (2003). Splanchnic metabolism of dairy cows through transition from late gestation through early lactation. Journal of Dairy Science, 86, 1201-1217. https://doi.org/10.3168/jds.S0022-0302(03)73704-7

Rhoads, R., Kim, J., Leury, B., Baumgard, L., Segoale, N., Frank, S., \& Boisclair, Y. (2004). Insulin increases the abundance of the growth hormone receptor in liver and adipose tissue of periparturient cows. Journal of Nutrition, 134, 1920-1927. https://doi.org/10.1093/jn/134.5.1020

Ribeiro, E. (2018). Lipids as regulators of conceptus development: Implications for metabolic regulation of reproduction in dairy cattle. Journal of Dairy Science, 101, 3630-3641. https://doi.org/10.3168/jds. 2017-13469

Ribeiro, E., Lima, F., Greco, L., Bisinotto, R., Monteiro, A., Favoreto, M., \& Santos, J. (2013). Prevalence of periparturient diseases on fertility of seasonally calving grazing dairy cows supplemented with concentrates. Journal of Dairy Science, 96, 5682-5697. https://doi.org/10.3168/jds.2012-6335

Roberts, C., Reid, I., Roelands, G., \& Patterson, A. (1981). A fat mobilisation syndrome in dairy cows in early lactation. Veterinary Record, 108, 7-9. https://doi.org/10.1136/vr.108.1.7

Roche, J. (2006). The effect of nutritional management of the dairy cow on reproductive efficiency. Animal Reproduction Science, 96, 282-296. https://doi.org/10.1016/j.anireprosci.2006.08.007

Roche, J., Friggens, N., Kay, J., Fisher, M., Stafford, K., \& Berry, D. (2009). Invited review: Body condition score and its association with dairy cow productivity, health, and welfare. Journal of Dairy Science, 92, 5769-5801. https://doi.org/10.3168/jds.2009-2431

Roche, J., Mackey, D., \& Diskin, M. (2000). Reproductive management of the postpartum cows. Animal Reproduction Science, 60-61, 703-712. https://doi.org/10.1016/S0378-4320(00)00107-X

Rodney, R., Celi, P., Scott, W., Breinhild, K., Santos, J., \& Lean, I. (2018). Effects of nutrition on the fertility of lactating cows. Journal of Dairy Science, 101, 5115-5133. https://doi.org/10.3168/jds.2017-14064

Rodriguez-Jimenez, S., Haerr, K., Trevisi, E., Loor, J., Cardoso, F., \& Osorio, J. (2018). Prepartal standing behavior as a parameter for early detection of postpartal subclinical ketosis associated with inflammation and liver function biomarkers in peripartal dairy cows. Journal of Dairy Science, 101, 8224-8235. https://doi.org/10.3168/jds.2017-14254

Rojas-Morales, P., Tapia, E., \& Pedraza-Chaverri, J. (2016). $\beta$-Hydroxybutyrate: A signaling metabolite in starvation response? Cellular Signalling, 28, 917-23. https://doi.org/10.1016/j.cellsig.2016.04.005

Roth, Z. (2018). Symposium review: Reduction in oocyte developmental competence by stress is associated with alterations in mitochondrial function. Journal of Dairy Science, 101, 3642-3654. https://doi.org/10.3168/ jds.2017-13389

Royal, M., Flint, A., \& Woolliams, J. (2002). Genetic and phenotypic relationships among endocrine and traditional fertility traits and production traits in Holstein-Friesian dairy cows. Journal of Dairy Science, 85, 958-967. https://doi.org/10.3168/jds.S0022-0302(02)74155-6

Rutter, L., \& Manns, J. (1987). Hypoglycemia alters pulsatile luteinizing hormone secretion in the postpartum beef cow. Journal of Animal Science, 64, 479-488. https://doi.org/10.2527/jas1987.642479x

Sakai, T., Hayakawa, T., Hamakawa, M., Ogura, K., \& Kubo, S. (1993). Therapeutic effects of simultaneous use of glucose and insulin in ketotic cows. Journal of Dairy Science, 76, 109-114. https://doi.org/10.3168/ jds.S0022-0302(93)77329-4 
Sangsritavong, S., Combs, D., Sartori, R., Armentano, L., \& Wiltbank, M. (2002). feed intake increases liver blood flow and metabolism of progesterone and estradiol-17beta in dairy cattle. Journal of Dairy Science, 85, 2831-2842. https://doi.org/10.3168/jds.S0022-0302(02)74370-1

Santos, J., Bisinotto, R., \& Ribeiro, E. (2016). Mechanisms underlying reduced fertility in anovulary dairy cows. Theriogenology, 86, 254-263. https://doi.org/10.1016/j.theriogenology.2016.04.038

Scharrer, E. (1999). Control of food intake by fat acid oxidation and ketogenesis Nutrition, 15, 704-14. https://doi.org/10.1016/S0899-9007(99)00125-2

Schillo, K. (1992). Effect of dietary energy on control of luteinizing hormone secretion in cattle and sheep. Journal of Animal Science, 70, 1271-1282. https://doi.org/10.2527/1992.7041271x

Schlumbohm, C., \& Harmeyer, J. (2004). Hyperketonemia impairs glucose metabolism in pregnant and nonpregnant ewes. Journal of Dairy Science, 87, 350-358. https://doi.org/10.3168/jds.S0022-0302(04) 73174-4

Schneider, J. (2004). Energy balance and reproduction. Physiology \& Behavior, 81, 289-317. https://doi.org/ 10.1016/j.physbeh.2004.02.007

Seifi, H., Leblanc, S., Leslie, K., \& Duffield, T. (2011). Metabolic predictors of post-partum disease and culling risk in dairy cattle. Veterinary Journal, 188, 216-220. https://doi.org/10.1016/j.tvj1.2010.04.007

Sheldon, I., Cronin, J., Goetze, L., Donofrio, G., \& Schuberth, H. (2009). Defining postpartum uterine disease and the mechanisms of infection and immunity in the female reproductive tract in cattle. Biology of Reproduction, 81, 1025-1032. https://doi.org/10.1095/biolreprod.109.077370

Sheldon, I., Cronin, J., Pospiech, M., \& Turner, M. (2017). Mechanisms linking metabolic stress with innate immunity in the endometrium. Journal of Dairy Science, 101, 3655-3664. https://doi.org/10.3168/ jds.2017-13135

Shimazu, T., Hirschey, M., Newman, J., He, W., Shirakawa, K., Le Moan, N., \& Verdin, E. (2013). Suppression of oxidative stress by $\beta$-hydroxybutyrate, an endogenous histone deacetylase inhibitor. Science, 339, 211-214. https://doi.org/10.1126/science.1227166

Siegel, H. (1995). Stress, strains and resistance. British Poultry Science, 36, 3-22. https://doi.org/10.1080/ 00071669508417748

Silva, J., Figueiredo, J., \& van den Hurk, R. (2009). Involvement of growth hormone (GH) and insulin-like factor (IGF) system in ovarian folliculogenesis. Theriogenology, 71, 1193-1208. https://doi.org/10.1016/ j.theriogenology.2008.12.015

Silva, M., dos Santos, D., Boison, S., Utsunomiya, A., Carmo, A., Sonstegard, T., \& Van Tassel, C. (2014). The development of genomics applied to dairy breeding. Livestock Science, 166, 66-75. https://doi.org/10.1016/ j.livsci.2014.05.017

Silva, P., Soares, H., Braz, W., Bombardelli, G., Clapper, J., Keisler, D., \& Chebel, R. (2017a). Effects of treatment of periparturient dairy cows with recombinant bovine somatotropin on health and productive and reproductive parameters. Journal of Dairy Science, 100, 3126-3142. https://doi.org/10.3168/jds.2016-11737

Silva, P., Weber, W., Crooker, B., Collier, R., Thatcher, W., \& Chebel, R. (2017b). Hepatic mRNA expression for genes related to somatotropic axis, glucose and lipid metabolisms, and inflammatory response of periparturient dairy cows treated with recombinant bovine somatotropin. Journal of Dairy Science, 100, 3983-3999. https://doi.org/10.3168/jds.2016-12135

Simianer, H., Solbu, H., \& Schaeffer, L. (1991). Estimated genetic correlations between disease and yield traits in dairy cattle. Journal of Dairy Science, 74, 4358-4365. https://doi.org/10.3168/jds.S0022-0302(91) 78632-3

Smith, K. L., Butler, W., \& Overton, T. (2009). Effects of prepartum 2,4-thiazolidinedione on metabolism and performance in transition dairy cows. Journal of Dairy Science, 92, 3623-3633. https://doi.org/10.3168/jds. 2008-1508

Sordillo, L., \& Aitken, S. (2009). Impact of oxidative stress on the health and immune function of dairy cattle. Veterinary Immunology and Immunopathology, 128, 104-109. https://doi.org/10.1016/j.vetimm.2008. 10.305 
Sordillo, L., \& Mavangira, V. (2014). The nexus between nutrient metabolism, oxidative stress and inflammation in transition cows. Animal Production Science, 54, 1204-1214. https://doi.org/10.1071/AN14503

Sordillo, L., \& Raphael, W. (2013). Significance of metabolic stress, lipid mobilization, and inflammation on transition cow disorders. Veterinary Clinics of North America: Food Animal Practice, 29, $267-278$. https://doi.org/10.1016/j.cvfa.2013.03.002

Spencer, T., Forde, N., \& Lonergan, P. (2015). The role of progesterone and conceptus-derived factors in uterine biology during early pregnancy in ruminants. Journal of Dairy Science, 99, 5941-5950. https://doi.org/ $10.3168 /$ jds.2015-10070

Strang, B., Bertics, S., Grummer, R., \& Armentano, L. (1998). Effect of long-chain fatty acids on triglyceride accumulation, gluconeogenesis, and ureagenesis in bovine hepatocytes. Journal of Dairy Science, 81, 728-739. https://doi.org/10.3168/jds.S0022-0302(98)75629-2

Suthar, V., Canelas-Raposo, J., Deniz, A., \& Heuwieser, W. (2013). Prevalence of subclinical ketosis and relationships with postpartum diseases in European dairy cows. Journal of Dairy Science, 96, 2925-2938. https://doi.org/10.3168/jds.2012-6035

Tamminga, S. (2006). The effect of supply of rumen degradable protein and metabolizable protein on negative energy balance and fertility in dairy cows. Animal Reproduction Science, 96, 227-239. https://doi.org/ 10.1016/j.anireprosci.2006.08.003

Taylor, V., Cheng, Z., Pushpakumara, P., Beever, D., \& Wathes, D. (2004). Relationships between the plasma concentrations of insulin-like growth factor-I in dairy cows and their fertility and milk yield. Veterinary Record, 155, 583-588. https://doi.org/10.1136/vr.155.19.583

Tharwart, M., Endoh, D., \& Oikawa, S. (2012). Hepatocytes adoptosis in dairy cows with fat infiltration of the liver. Canadian Journal of Veterinarian Research, 76, 241-247.

Trevisi, E., Amadori, M., Cogrossi, S., Razzuoli, S., \& Bertoni, G. (2012). Metabolic stress and inflammatory respone in high-yielding, periparturient dairy cows. Research in Veterinary Science, 93, 695-704. https://doi.org/10.1016/j.rvsc.2011.11.008

Tsuruta, S., Lourenco, D., Misztal, I., \& Lawlor, T. (2017). Genomic analysis of cow mortality and milk production using a threshold-linear model. Journal of Dairy Science, 100, 7295-7305. https://doi.org/ $10.3168 /$ jds.2017-12665

Urdl, M., Gruber, L., Obritzhauser, W., \& Schauer, A. (2015). Metabolic parameters and their relationship to energy balance in multiparous Simmental, Brown Swiss and Holstein cows in the periparturient period as influenced by energy supply pre-and post-calving. Journal of Animal Physiology and Animal Nutrition, 99, 174-189. https://doi.org/10.1111/jpn.12178

Uribe, H., Kennedy, B., Martin, S., \& Kelton, D. (1995). Genetic parameters for common health disorders of Holstein. Journal of Dairy Science, 78, 421-430. https://doi.org/10.3168/jds.S0022-0302(95)76651-6

USDA. (1996). Part I: Reference of 1996 dairy management practices. USDA: Animal and Plant Health Inspection Service (APHIS), Veterinary Service (VS), Center for Epidemiology and Animal Health (CEAH), National Animal Health Monitoring System (NAHMS), Fort Collins, CO.

USDA. (2016). Dairy 2014, milk quality, milking procedures and mastitis in the United States, 2014. USDA: Animal and Plant Health Inspection Service (APHIS), Veterinary Services (VS), Center for Epidemiology and Animal Health (CEAH), National Animal Health Monitoring System (NAHMS), Fort Collins, CO.

Van Dorp, T., Dekkers, J., Martin, S., \& Noordhuizen, J. (1998). Genetic parameters of health disorders, and relationship with 305-day milk yield and conformation traits of registered Holstein cows. Journal of Dairy Science, 81, 2264-2270. https://doi.org/10.3168/jds.S0022-0302(98)75806-0

Van Saun, R., \& Sniffen, C. (2014). Transition cow nutrition and feeding management for disease prevention. Veterinary Clinics of North America: Food Animal Practice, 30, 689-719. https://doi.org/10.1016/j.cvfa. 2014.07.009

Velasques, M., Spicer, L., \& Wathes, D. (2008). The role of endocrine insulin-like growth factor-I (IGF-I) in female bovine reproduction. Domestic Animal Endocrinology, 35, 325-342. https://doi.org/10.1016/ j.domaniend.2008.07.002

Vernon, R. (1998). Homeorhesis (pp. 64-73). Hannah Research Institute. 
Vernon, R. (2005). Lipid metabolism during lactation: A review of adipose tissue-liver interactions and the development of fat acids. Journal of Dairy Research, 72, 460-469. https://doi.org/10.1017/S00220299 05001299

VIT (Vereinigte Informationssysteme Tierhaltung). (2016). Jahresbericht 2016. Retrieved from http://www.vit.de/fileadmin/user_upload/wirsindvit/jahresberichte/vit-JB2016-samt.pdf

Vukasinovic, N., Bacciu, N., Przybyla, C., Boddhireddy, P., \& DeNise, S. (2017). Development of genetic and genomic evaluation for wellness traits in US Holstein cows. Journal of Dairy Science, 100, 428-438. https://doi.org/10.3168/jds.2016-11520

Wade, G., \& Jones, J. (2004). Neuroendocrinology of nutritional infertility. Regulatory, Integrative and Comparative Physiology, 287, R1277-1296. https://doi.org/10.1152/ajpregu.00475.2004

Walsh, R., Walton, J., Kelton, D., LeBlanc, S., Leslie, K., \& Duffield, T. (2007). The effect of subclinical ketosis in early lactation on reproductive performance of postpartum dairy cows. Journal of Dairy Science, 90, 2788-2796. https://doi.org/10.3168/jds.2006-560

Walsh, S., Williams, E., \& Evans, A. (2011). A review of the causes of poor fertility in high milk producing cows. Animal Reproduction Science, 123, 127-138. https://doi.org/10.1016/j.anireprosci.2010.12.001

Waltner, S., McNamara, J., \& Hillers, J. (1993). Relationship of body condition scores of production variables in high producing Holstein dairy cattle. Journal of Dairy Science, 76, 3410-3419. https://doi.org/10.3168/ jds.S0022-0302(93)77679-1

Wangler, A., \& Sanftleben, P. (2007). Behandlungshäufigkeit bei Milchkühen in Praxisbetrieben in Abhängigkeit von der Milchleistung. Tierärztliche Praxis (G), 35, 408-413. https://doi.org/10.1055/s-0038-1624020

Wathes, D., Cheng, Z., Bourne, N., Taylor, V., Coffey, M., \& Brotherstone, S. (2007). Differences between primiparous and multiparous dairy cows in the inter-relationships between metabolic traits, milk yield and body condition score in the periparturient period. Domestic Animal Endocrinology, 33, $203-25$. https://doi.org/10.1016/j.domaniend.2006.05.004

Wathes, E. (2012). Mechanisms linking metabolic status and disease with reproductive outcome in dairy cow. Reproduction of Domestic Animal, 47(Suppl. 4), 304-312. https://doi.org/10.1111/j.1439-0531.2012.02090.x

Webb, R., Garnsworthy, P., Gong, J., Robinson, R., \& Wathes, D. (1999). In J. Oldham, G. Simm, A. Groen, B. Nielsen, J. Pryce, \& T. Lawrence (Eds.), Metabolic Stress in Dairy Cows (Occasional Publication No. 24, pp. 99-112). Pencuit, Midlothian: British Society of Animal Science. https://doi.org/10.1017/S14639815 00043119

Weller, J., Ezra, E., \& Ron, M. (2017). Invited review: A perspective on future of genomic selection in dairy cattle. Journal of Dairy Science, 100, 8633-8644. https://doi.org/10.3168/jds.2017-12879

Westwood, C., Lean, I., \& Garvin, J. (2002). Factors influencing fertility of Holstein dairy cows: A multivariate description. Journal of Dairy Science, 85, 3225-3237. https://doi.org/10.3168/jds.S0022-0302(02)74411-1

White, H. (2015). The role of TCA cycle in ketosis and fat liver in periparturient dairy cows. Animals, 5, 793-802. https://doi.org/10.3390/ani5030384

Wiltbank, M., Lopez, H., Sartori, S., Sangritavong, S., \& Gümen, A. (2006). Changes in reproductive physiology of lactating dairy cows due to elevated steroid metabolism. Theriogenology, 65, 17-29. https://doi.org/ 10.1016/j.theriogenology.2005.10.003

Wiltbank, M., Salith, S., Atii, M., Luo, W., Borman, C., Ottobre, J., \& Sarton, R. (2012). Comparison of endocrine and cellular mechanism regulating the corpus luteum of primates and ruminants. Animal Reproduction, 9, 242-259. https://doi.org/10.1542/peds.2008-1871

Xie, Z., Zhang, D., Chung, D., Tang, Z., Huang, H., Dai, L., Qi, S., \& Zhao, Y. (2016). metabolic regulation of gene expression by histone lysine $\beta$-hydroxybutyrylation. Molecular Cell, 62, 194-206. https://doi.org/ 10.1016/j.molcel.2016.03.036

Yelich, J., Wettemann, R., Marston, T., \& Spicer, L. (1996). Luteinising hormone, growth hormone, insulin-like growth factor-I, insulin and metabolites before puberty in heifers fed grain at two rates. Domestic Animal Endocrinology, 13, 325-338. https://doi.org/10.1016/0739-7240(96)00046-X 
Zarrin, M., De Matteis, L., Vernay, M., Wellnitz, O., van Dorland, H., \& Bruckmaier, R. (2013). Long-term elevation of $\beta$-hydroxybutyrate in dairy cows through infusion: Effects on feed intake, milk production, and metabolism. Journal of Dairy Science, 96, 2960-2972. https://doi.org/10.3168/jds.2012-6224

Zerbin, I., Lehner, S., \& Distl, O. (2015). Genetics of bovine abomasal displacement. Veterinary Journal, 204, 17-22. https://doi.org/10.1016/j.tvj1.2015.02.013

Zhu, L., Armentano, L., Bremmer, D., Grummer, R., \& Bertics, S. (2000). Plasma concentrations of urea, ammonia, glutamine around calving and the relation to hepatic triglyceride, to plasma ammonia removal and blood acid-base balance. Journal of Dairy Science, 83, 734-740. https://doi.org/10.3168/jds.S00220302(00)74935-6

Zulu, V., Nakao, T., \& Sawamukai, Y. (2002). Insulin-like growth factor-1 as possible hormonal mediator of nutritional regulation of reproduction in cattle. Journal of Veterinary Medical Science, 64, 657-665. https://doi.org/10.1292/jvms.64.657

\section{Copyrights}

Copyright for this article is retained by the author(s), with first publication rights granted to the journal.

This is an open-access article distributed under the terms and conditions of the Creative Commons Attribution license (http://creativecommons.org/licenses/by/4.0/). 